\title{
An Early Triassic (Smithian) stromatolite associated with giant ooid banks from Lichuan (Hubei Province), South China: environment and controls on its formation \\ Yuheng Fanga ${ }^{\mathrm{a}}$, Zhong-Qiang Chen ${ }^{\mathrm{a}, *}$, Stephen Kershaw ${ }^{\mathrm{b}}$, Mao Luo ${ }^{\mathrm{a}, \mathrm{c}}$ \\ a State Key Laboratory of Biogeology and Environmental Geology, China University of Geosciences (Wuhan), Wuhan 430074, China \\ ${ }^{\mathrm{b}}$ Institute for Environment, Brunel University, Uxbridge, UB8 3PH, UK \\ ${ }^{c}$ School of Life and Environmental Sciences, Deakin University, Melbourne Burwood Campus, 221 Burwood Highway, Burwood, VIC 3125, Australia. \\ * Corresponding author: zhong.qiang.chen@cug.edu.cn
}

\begin{abstract}
As a consequence of the Permian-Triassic mass extinction (PTME), the microbe-dominated ecosystems proliferated in shallow marine settings worldwide, and they are indicated by the widespread 'anachronistic facies' in the Lower Triassic successions. Of these, both microbialite and giant ooid are most widely distributed, and these unusual biosedimentary structures not only are commonly present in the Permian-Triassic boundary beds, but also extend through the entire Lower Triassic successions. Here, we report a probably the known thickest Early Triassic stromatolite, which developed within giant ooid banks from the late Smithian succession (Lower Triassic) of the Lichuan area, western Hubei Province, South China. Therein a $\sim 18 \mathrm{~m}$ thick stromatolite is embedded within $\sim 30 \mathrm{~m}$ thick oolitic limestones that crop out at the upper Daye Formation. The associated conodonts suggest a late Smithian (Early Triassic) age for the stromatolite-ooid complex. These pronounced ooids can be categorized into circular, compound, superficial, and irregular ooids. Stromatolites exhibit domical, stratified columnar, wavy laminated, cabbage-shaped, roll-up, and conical structures. Stromatolites are overlain by thick oolitic limestone, implying that the demise of the Lichuan stromatolite may be attributed to destruction by agitated shallow waters. Four types of microbially induced microstructures are recognizable in stromatolites. The layers with intense fluorescence indicative of microbial organomineralization contribute to the formation of the ooids. Moreover, the common occurrence of nanometer-scale textures relative to the formation of the dolomite both in stromatolite and ooids, as well as authigenic quartz grains commonly preserving in stromatolite, could be attributed to abundant organic matters in water, resulting from microbial proliferations. As such, microbes were probably extremely flourishing in both eastern and western margins of the Palaeo-Tethys Ocean during middle Early Triassic, suggesting the long-term degradation of marine ecosystems after the PTME.
\end{abstract}

Keywords: stromatolites; giant ooid; microbial origin; ecosystem degradation; Early Triassic; Lichuan; South China

\section{Introduction}

The aftermath of the Permian-Triassic mass extinction (PTME) was a tough time for the inhabitation of metazoans but witnessed the widespread proliferation of microbe-dominated communities in marine and terrestrial ecosystems (Pruss and Bottjer, 
1999; Lehrmann, 1999; Kershaw et al., 1999, 2001, 2007, 2011, 2012; Ezaki et al., 2003, 2008, 2012; Wang et al., 2005; Pruss et al., 2006; Baud et al., 2007; Mary and Woods, 2008; Chen and Benton, 2012; Chen et al., 2014; Lehrmann et al., 2015; Chu et al., 2015; Tu et al., 2016; Luo et al., 2016; Xu et al., 2016; Fang et al., 2016). Such a phenomenon of metazoan depletion coupled with microbial proliferation could be triggered by recurrent environmental shocks such as global warming, oceanic acidification, and widespread anoxia that may also have prevailed in the PTME but repeated over the next 5 Myr until latest Olenekian (Chen and Benton, 2012). Thus, unusual biosedimentary structures indicate the Earth's ecosystems have changed fundamentally after the greatest biocrisis of Earth history (Erwin, 2006; Chen and Benton, 2012). To date, six peak temporal pulses of microbialite occurrence have been recognized from the immediate aftermath of the PTME to the biotic full recovery period in middle-late Anisian (Chen and Benton, 2012), corresponding to the early Griesbachian, late Griesbachian to early Dienerian, early Smithian, late Smithian, late Spathian, and early Anisian, respectively (Pruss et al., 2006; Baud et al., 2007; Kershaw et al., 2012; Chen et al., 2014; Luo et al., 2014). Unlike metazoan reef buildups, these post-extinction microbial reef deposits possess relatively low geometry, often 1-5 m in thickness. Here, we report an $18 \mathrm{~m}$-thick stromatolite deposit that grew on a thick giant ooid bank from the Lower Triassic Daye Formation of the Lichuan area, western Hubei Province, South China (Fig. 1). The newly found stromatolite-oolite complex is $>30 \mathrm{~m}$ in thickness and is preserved in the upper part of the fourth member of the Daye Formation (Fig. 2). Apart from the exceptionally thick stromatolite, giant ooids from the Lichuan buildup are also pronounced in the field (Mei et al., 2008). Recently, these giant ooids have also been considered as the precipitation products of microbe activities in saturated seawater in carbonate settings and commonly occurred in the aftermath of major mass extinctions (Li et al., 2013, 2015). Geobiological features of both stromatolites and giant ooid bank therefore provide insights into the seawater conditions in the aftermath of the LPME in carbonate platforms.

This paper aims to document geobiologic features of an early Triassic stromatolite-giant ooid complex from Lichuan City, Hubei Province, South China (Fig. 1) and attempts to test its biogenesis. Geobiologic process of key nanometer-scale structures in dolomite and authigenic quartz grains embedded in stromatolite and/or oolite is also emphasized based on detailed micro-analysis. The possible constructors of stromatolite and their growing environments are also discussed in a broad context by comparising the Lichuan example with other post-extinction microbialites from around the world.

\section{Geological setting and stratigraphy}

The Lichuan stromatolite-oolite bank complex is exposed at the Daxiandong quarry, $\sim 12 \mathrm{~km}$ northwest of Lichuan City, western Hubei Province, South China (Fig. 1). The Lichuan area was located at the northwestern margin of the upper Yangtze Platform, which was a huge inheriting carbonate platform lying on the middle of the South China Block during the Permian-Triassic (P-Tr) transition (Feng et al., 1997). Therein the Daye Formation is dominated by shallow platform facies carbonates and is subdivided into four members: black shale (Member 1), dark grey limestone (Member 2), reddish micrites (Member 3), and oolite-dominated micrite limestone (Member 4) (Wang et al., 1981). 
Of these, Member 4 is well exposed at the Daxiandong quarry, and comprises five beds: $\sim 1 \mathrm{~m}$-thick oolite resting on light reddish micritic limestone (Bed 1), massive stromatolite (>14 m in thickness) (Bed 2), 1 m-thick oolite (Bed 3), $\sim 2$ m-thick stromatolite with thin rotelliform ooilite layers (Bed 4), and $12 \mathrm{~m}$-thick oolite (Bed 5), which is also the top of the Daye Formation (Fig. 3B). Thus, three oolite units interbedded with two stromatolite layers characterize the upper Daye Formation. Oolite units thicken, with enlarging ooids up the section. The stromatolite-ooilite complex is capped by the medium-bedded laminated muddy limestone of the Jialingjiang Formation (Fig. 3A).

Except for the stromatolites, the ooilite shoaling and bank facies characterize the Daye Formation successions in the Yangtze Platform of the eastern Sichuan Basin. Wu et al. (1994) recognized four development stages of ooid shoals and banks during the Early Triassic (Fig. 2). Controlled by transgression-regression progress in the Induan to Olenekian age of the Early Triassic, the stromatolite-oolite complex has undergone the obvious progradation from the west to the east. Thus, resulting from this sedimentary process, these stromatolite-oolite complex have the thickness of $>30$ meters, which developed in the upper part of the Daye Formation.

Wang et al. (1981) established conodonts Neospathodus dieneri, Neospathodus pakistanensis, and Neospathodus waageni Zones from the middle and upper parts of the Daye Formation in the neighboring Daxaindong section of Lichuan area. The first zone is characteristic of the Dienerian fauna, while the latter two are usually assigned to early Smithian in age in South China (Zhao et al., 2007, 2013). The Lichuan stromatolite-oolite complex is embedded between the N. pakistanensis and N. waageni Zones, and thus is early Smithian in age (Fig. 3B).

\section{Materials and methods}

Polished slabs of stromatolite were made for observing mcro-structures. Petrologic thin sections of both stromatolites and oolites were made to examine fabrics and diagenetic features. In order to observe possible microbial signatures within stromatolites and oolites, some freshly broken and polished chips of laminated structure within stromatolites and ooids were prepared for Scanning Electron Microscope (SEM) imaging analysis. These samples were cleaned first by diluted water and then etched with $0.5 \%$ chloride acid for 3-5 s, followed by a second rinse by diluted water and ethyl alcohol. Some samples for SEM analysis were polished with 200 mesh diamond dust before chemical etching and cleaning. Samples were all coated with platinum for surface texture analysis and energy dispersive X-ray spectrometry (EDS) analysis. Surface texture micro-analysis was initially conducted using the Field Emission Scanning Electron Microscope Hitachi SU8010 equipped at the State Key Laboratory of Biogeology and Environmental Geology, China University of Geosciences (Wuhan), China. Fluorescent imaging analysis is undertaken to check for the distribution of residual organic matter in stromatolite using a fluorescent microscopy equipped at the China University of Geosciences (Wuhan), China. Terminology and methods describing stromatolite features follow Shapiro (2000), who observed and classified microbial fabrics at macro-, meso-, and micro-structural scales. 


\section{Results}

\subsection{Macro- and meso-structures of stromatolite}

On the outcrop, domical or columnar stromatolites are densely compacted laterally and closely piled up longitudinally (Fig. 4A-C). Stromatolites from outcrop exhibit a wide variety of macrostructures: domical, stratified columnar, wavy laminated, cabbage-shaped, roll-up, and conical structures (Figs 4-5), which are displayed on a large limestone wall at the quarry (Fig. 4A). Of these, the cabbage-like forms, 20-50 cm wide and $20-40 \mathrm{~cm}$ high, are rather pronounced on the wall (Figs 4B-C, 5B). Columnar stromatolites are $\sim 20 \mathrm{~cm}$ wide and $30 \mathrm{~cm}$ high (Fig. 4E), and its tops were eroded by agitated waves and surrounded by ooids occasionally (Fig. 4E). Some columns branch upwards (Fig. 4D). The wavy laminated stromatolites contain crinkled thin layers with each layer being $\sim 1 \mathrm{~cm}$ thick and extending laterally (Fig. 5A). In some cases, the crinkled thin layers of stromatolites form roll-up structures (Fig. 5C-D), which indicate soft microbial layers stirred by strong waves. Domical stromatolites are $>20 \mathrm{~cm}$ high and $30 \mathrm{~cm}$ wide (Fig. 5E). Conical stromatolites are $\sim 10 \mathrm{~cm}$ wide and $>20 \mathrm{~cm}$ high (Fig. 5F). Some single stromatolites show multiple macrostructures at the same time. They all, however, have alternations of laminae. The alternating dark-colored thin laminae and light-colored laminae are conspicuous on polished blocks (Fig. 5B-E).

\subsection{Micro- to ultra-structures of stromatolites}

Under polarizing microscope, stromatolites are characterized by undulating laminations embedding with rare skeletal grains (Fig. 6A). The diffuse laminated, reticular, intraclastic, and irregular clotted microstructures are recognized from the Lichuan stromatolites, and they are described as below.

\subsubsection{Diffuse laminated microstructures (DLMs)}

The DLM is dominated by poorly-defined laminae in variable thicknesses (Fig. 6A). Dark colored laminae consist of concentrations of organic inclusions that extend laterally for millimeters to centimeters. They are separated by light colored zones of microcrystalline carbonate with few inclusions. The contact between dark and light colored laminae is marked by a gradual variation in color, reflecting variable concentrations of organic inclusions and crystal sizes.

Laminae are different in thickness and embrace varied geometry of couplets of dark laminae and interstitial microcrystalline carbonate. Abundant laminated microstructures consist of dark laminae that vary between 30 and 50 microns in thickness. Some dark colored laminae are much thicker, 100-300 microns in thickness (Fig. 6A). Both thin and thick laminae appear as planar geometries in thin section and, occasionally, as slightly domal, or contorted, or rolled up in shapes. Some crinkled laminations form the reticular microstructures (Fig. 6B-C; see below).

\subsubsection{Reticular microstructures (RMs)}


The RM is typically preserved in stromatolite (Figs $6 \mathrm{~B}-\mathrm{C}, 7 \mathrm{~A}-\mathrm{B}$ ). They are comprised of light-colored, coarse calcite and dark-colored micrite as well as opacity materials (Figs 6B-C, 7A-B). RMs form thin micritic laminae in low power lens (Fig. 6A). Reticulations are loosely combined and form clotted textures in some parts, similar to thrombolite textures (Figs 6B, 7A). Fabrics that construct the dark-colored reticular frameworks are 20-100 $\mu \mathrm{m}$ thick and composed of concentrations of nodes that usually extend laterally (Fig. 6C). Fabrics are occasionally arc-shaped or semi-circular, and construct chamber-like structures (Fig. 7B).

\subsubsection{Intraclastic microstructure (IM)}

The IM is characterized by brown colored, isolated intraclasts (Fig. 7C-D), which are irregular, usually larger than $300 \mu \mathrm{m}$ in size, and made up of coarse dolomite grains. Dark colored micrite envelope coating intraclasts is distinct, and may have resulted from decompositions of microbial mat that wrapped up intraclasts before lithofication and diagenesis (Fig. 7C-D). Matrix is divided by clumps and shows vein-shaped microstructure. Vein-shaped microstructure is $100-200 \mu \mathrm{m}$ wide and partially similar to bird-foot structure. SEM imaging clearly exhibits that intraclasts are made up of subhedral to euhedral dolomites, and possess high magnesium contents (Fig. 8A-C).

\subsubsection{Irregular clotted microstructure (ICM)}

The ICM consists of diffuse to distinct irregularly shaped patches or rounds of dark microcrystalline carbonates. These clots vary in size, shape, and spacing (Fig. 7E-F). They are typically elongate and irregularly shaped, and are occasionally associated with ooids, indicating active disturbance of currents (Fig. 7E). Clots possess diameter ranging from $<100 \mu \mathrm{m}$ to $500 \mu \mathrm{m}$ and are surrounded by light colored microcrystalline carbonate. The alignment of dispersed clots commonly defines a diffuse lamination (Fig. 7E). Some clots under high-magnification microscope also show that smaller dark rounded microclot individuals are visible at their outer margins (Fig. 7F). In contrast to diffuse laminated microstructures, ICMs do not occur within mesoclots.

\subsubsection{Ultra-structures of stromatolites}

Under the SEM, quartz crystals are commonly present in stromatolite microstructures. They coexist with minute dolomite rhombs within stromatolitic laminae. Quartz crystals are usually euhedral in outline (Fig. 8D), showing no signs of abrasion. They scatter in stromatolite laminae and do not concentrate to form layers or horizons, which are typical of detrital quartz grains. These crystals therefore are likely authigenic in origin, showing no sign of transportation (Fig. 8D). Dolomite in stromatolite laminae has distinct nanometer-scale structure in its surfaces (Fig. 8E-F). These tiny objects are mostly amorphous. Some nano-particles are lumpy-shaped, and have diameter ranging from $100 \mathrm{~nm}$ to $200 \mathrm{~nm}$ (Fig. 8E-F).

\subsection{Macro- and meso-structures of ooids}


Ooids are a common component of shallow facies of the Upper Daye Formation and are readily observed on outcrop (Fig. 9). They are typically present in packstone and grainstone, and appear massive ooid aggregates (Fig. 9B-C). Some ooids also concentrate in some thin layers, $0.3-1.5 \mathrm{~cm}$ in thickness, to form 'ooid laminations' (Fig. 9A). Individual ooids are spherical, ellipsoidal or even irregularly rounded in shapes, and are typically $0.2-2 \mathrm{~mm}$ in diameter, although few ooids are $>2 \mathrm{~mm}$ in diameter (Fig. 9B-C).

\subsection{Micro- to ultra-structures of ooids}

The Lichuan ooids can be categorized into four types: circular, compound, superficial (thin), and irregular ooids (Fig. 10). Circular ooids are spherical to ellipsoidal in outline, and are usually poorly sorted, well-rounded, typically $0.2-2 \mathrm{~mm}$ in diameter. They comprise micrite peloidal or sparitic nuclei surrounded by concentrically laminated to homogenous micrite coating layers (Fig. 10B-C). Individual lamina within concentrically-laminated ooids ranges from 10 to $30 \mu \mathrm{m}$ in thickness. The laminae consist of alternating layers of equal or nearly equal thickness of dark coloured micrite and light coloured micrite that embeds occasionally euhedral dolomite crystals (Fig. 10B-D). Compound forms are composed of multiple previously cemented ooids (Fig. $10 \mathrm{E}-\mathrm{F})$. Superficial ooids have very thin cortical coating and specifically ooid in which the thickness of the accretionary coating is less, or commonly far less than the radius of the nucleus (see smaller ooids in Fig. 10A). The last type of ooids includes irregularly shaped or broken, regrowth grains (Fig. 10D). In some samples, ooid layers alternate with relatively dark coloured stromatolite layers (Fig. 11). Dark coloured layers between two ooid layers are characterized by their cross-bedding feature and, sometimes, eroded by ooid layers. Ooids occasionally are notable by their "ghost" texture, probable resulting from dissolution during diagenesis (Fig. 11). In the examination under the fluorescence microscope, dark-coloured laminae show intense fluorescence when comparing with nonand very weak fluorescence within light-coloured layers (Fig. 12).

SEM analysis reveals that the cortices of ooids are composed of micrite with an internal fabric that ranges from distinctly concentrically laminated to homogenous and dense (Fig. 13). Ooids are commonly rimmed by bladed cement and between the ooids' space, is occluded by blocky calcite cement (Fig. 13A-B). Ooid nuclei are usually comprised of sparry dolomite, and the dolomite nuclei have distinct contact with outer micritic layers (Fig. 13C-E). At magnifications of 130,000× and greater, nanometer-scale features were readily observed within dolomite rhombs (Fig. 13F). These tiny particles are spherical to ovate, isolated rod-shaped or lumpy-shaped, with diameter ranging from $50 \mathrm{~nm}$ to $200 \mathrm{~nm}$ (Fig. 13F).

\section{Discussion}

\subsection{Depositional environment of the stromatolite-oolite complex}

The Lichuan stromatolites grew initially either on grainstone or oolitic limestone in shallow, below the wave-swept shoals on a carbonate platform (Fig. 2). Substratum oolites represent agitated conditions, which prejudiced construction of stromatolite. 
Strong water currents even physically eroded stromatolite underneath. When environmental conditions became hospitable for microbes to settle on either ooid grains or relative palaeo-highs of oolitic sea floor, they grew stromatolites. Modern domal stromatolites with the best lamination in Hamelin Pool of Shark Bay, Western Australia, grow under the mean tidal surface (Suosaari et al., 2016). The Lichuan giant stromatolites are even more densely built than modern stromatolites (Fig. 4), and thus indicate a slightly higher (or lower) energy habitat than the Shark Bay stromatolites.

\subsection{Biogenic origin and geobiologic processes associated with accretion of the Lichuan stromatolites}

\subsubsection{Lithification of microbial microstructures in stromatolites}

The Lichuan stromatolites show a wide variety of microfabrics. Of these, the most common microbial lamination type is the diffuse laminated microstructure. Enlargement of diffuse dark laminae displays diffusive clotted or reticular structures, which have irregular boundaries to the adjacent light-coloured areas. Similar microstructures have also been observed from the Neoproterozoic stromatolite deposits of the Beck Spring Dolomite, ranging from distinct to diffusive laminated/clotted structures (Harwood and Summer, 2012). The diffusive features are thought to have resulted from the different timing of lithification relative to the growth and decay of the microbial communities. The distinct laminated/clotted structures may have originated from an early cementation of microbial communities with minimal degradation, whereas the diffusive laminated/irregular clotted structures may have resulted from an early degradation of microbial communities and later cementation (Harwood and Sumner, 2012). Such interpretation is also plausible for the formation of diffusive microclots in the Lichuan stromatolite. The Lichuan reticular microstructures are similar to reticulate microfabrics in stromatolites near the Permian-Triassic boundary in Hungary (Hips and Haas, 2006). The reticulate appearance of these laminae was interpreted to be attributed to winnowing of mat particles by weak currents (Hips and Haas, 2006). These microfabrics appear to be cavernous (Fig. 6C), and the dark-coloured filiform micrite probable represents calcified extracellular polymeric secretions (EPS), and/or the filiform micrite itself may represent mucus or biofilms generated by microbes (Noffke et al., 2003). The pronounced clotted structures of the Lichuan stromatolites are similar to Peloid-A2.2 defined by Adachi et al (2004). The latter were possibly formed through calcification of assemblage (colony) of coccoidal microbes and/or by the aggregation of smaller individual peloids (Adachi et al., 2004).

\subsubsection{Biogenic related minerals in Lichuan stromatolite}

SEM imaging unravels the common occurrence of nanometer-scale textures relative to the formation of the dolomite and to move forward, relative to microbial activities. Moreover, ubiquitous occurrence of authigenic microquartz crystals in association with clay minerals implies that the formation of micro-quartz crystals is attributed to microbial reduction by sulfate reducing bacteria (RSB) (Luo et al., 2016).

Some modern examples suggest that microbial sulphate reduction under anoxic 
conditions can promote dolomite precipitation by removing sulphate and reducing the kinetic inhibition of dolomite formation (Warthmann et al., 2000; Wright and Wacey, 2005; Krause et al., 2012). Several lines of evidence indicate the existence of the SRB-induced microbial formation of dolomite in the Lichuan stromatolite. As described above, the Lichuan stromatolite has abundant nano-sized lumpy-shaped textures that form amorphous aggregates. Comparable structures were also reported by Gournay et al (1999), who interpreted such nanometer-scales textures, in dolomite surface, precipitated in organic-rich, bacterial environment.

Moreover, authigenic quartz grains in conjunction with minute rhombic moulds are also rather abundant in stromatolitic laminae. The formation of euhedral quartz crystals has been interpreted as a result of lowered $\mathrm{pH}$ value by sulfide oxidizing, in which sulfide was produced by sulfate reduction (Chafetz and Zhang, 1998). As a result, the growth of euhedral authigenic quartz may indicate the bacteria sulfate reduction and sulfide oxidation processes (Friedman and Shukla, 1980). Some platy clay minerals attached to authigenic quartz surfaces or occluded within amorphous quartz crystals (Fig. 8D). These quartz crystals show no sign of abrasion on crystal surface, thus precluding a detrital origin and transportation. But it should also be noted that the possibility that those euhedral quartz grains originated from volcanism cannot be ruled out because volcanic eruptions have also produced many morphologically same authigenic quartz recorded in the P-Tr boundary successions in South China (Yin et al., 1992; Gao et al., 2013).

\subsection{Biogenetic origin and geobiologic process associated with formation of Lichuan ooids}

Giant ooids have been widely reported from the $\mathrm{P}-\mathrm{Tr}$ boundary beds worldwide ( $\mathrm{Li}$ et al., 2013, 2015). The main controls on the generation of giant ooids are attributed to reduced nucleus supply, increased growth rate, and higher environmental energy levels (Sumner and Grotzinger, 1993). Lower supply of skeletal grains means reduced supply of nuclei. What's more, the absence of a dominant skeletal sink of calcium carbonate influences both regional carbonate saturation state and local carbonate removal mechanism (Payne et al., 2006). Growth rate of ooids highly relies on carbonate saturation state (Sumner and Grotzinger, 1993). Environmental energy levels are commonly high in oolitic facies. Carbonate ramps possess unprotected margins that allow waves and currents to create more agitated conditions along the shallow water facies, forming a narrow ooid band on the Yangtze carbonate platform (Fig. 2). Only when the energy threshold needed to put in motion an ooid of a given size is exceeded, mobilization and growth of ooids can occur. Giant ooid usually have larger energy thresholds than normal ooid (Heller et al., 1980). Episodic hydrodynamic events such as storms, occasional strong tidal wave, and gale wind, may cause higher energy condition, leading to formation, destruction, and/or re-cementation of giant ooids (Fig. 10D). Such a process would be repetitive as long as the mass of ooid grains can float under highest energy condition. Stromatolite-oolite complex may indicate alternating appearance of high and low energy conditions.

The origin of dolomite has long been enigmatic mainly due to its common occurrences in ancient rocks but rare presence in modern marine environment (Arvidson and MacKenzie, 1999). Microbial mediation during dolomite formation potentially 
resolves this long-stand debate (Vasconcelos and McKenzie, 1997; Burne et al., 2000). Dolomitization is very common in various Lichuan ooid grainstones, and dolomite shows abundant nanometer-scale structures that resemble those observed by Gournay et al (1999). These features provided corroborating evidence for the formation of dolomite in organic-rich environments under near-surface conditions (Gournay et al., 1999). Culture experiments by Warthmann et al. (2000) demonstrated that modern species of sulfate-reducing bacteria are capable of mediating dolomite formation in a synthetic anoxic hypersaline habitat. Typical dumbbell-shaped dolomites appear to be uniquely mediated by sulfate reducing microbes (Warthmann et al., 2000). Though no dumbbell-shaped objects are detected in the Lichuan ooids and stromatolites, similar size amorphous nano-scale dolomite may also have genetic relationship to sulfate reducing microbes.

\subsection{Growth and environmental stress of the Lichuan giant stromatolite}

Modern stromatolite is reported from the brackish waters of Lake Clifton of Western Australia, the hypersaline waters of Hamelin Pool in Shark Bay, and the open marine environments of the Bahamas (Andres et al., 2006; Morse et al., 1984). Similarities between the Lichuan stromatolites and modern "giant" stromatolites are striking. They are comparable in size and general morphology, in possessing both broad convex-up lamination and large columnar structures (Figs 4-5). Moreover, the Lichuan stromatolites show constructing as well as destructing structures (Fig. 4D-E) that are surrounded by ooid shoal deposits. The Lichuan stromatolite colonized broad, essentially oolitic substrates, and this may account for their less steep sided, typically domical shape.

Lichuan stromatolite also provides insights into the ecology of ancient microbial communities. Microbial calcite producing communities flourished as higher organisms were nearly absent due to rapidly changing environmental condition or the sequelae of the Permian-Triassic mass extinction. Stromatolites and oolites bearing beddings of the Upper Daye Formation are nearly devoid of fossils, body fossils as well as trace fossils. The reason of this scarceness may be rapidly changing environmental conditions as the shallow and belt-like seacoast has no buffering capacity against fluctuations of various environmental parameters. The etched surfaces of the top of the stromatolites resulted from the wave's washing against the stromatolites, leaving stromatolite fragments re-deposited in the interval between columns of stromatolites (Fig. 4E). Some prerequisites of stromatolitic growth can be deduced from observations in the field. Wave strength and mud content are the main influence factors on the formation of stromatolites. On one hand, high energy conditions are preference to the formation of ooids, even giant ooids, and prejudice to the formation of stromatolites. On the other hand, high mud content water or mud layers excluded stromatolites or terminated their growth. The microbial community did not survive a mud coverage or muddy water. This effect may be the reason for their restriction to the distribution only on the oolitic shore of the Upper Daye Formation. The mud banded limestone of the overlying Jialingjiang Formation indicates high mud content in seawater, which terminated the deposit of oolites and stromatolites.

Protective stress to deter competitors will promote stromatolite growth (Chen and Benton, 2012) and may be provided by a variety of factors, including hypersalinity 
(Garrett, 1970) or mobile-sediment (Dravis, 1983). These are not mutually exclusive and could act together. The Lichuan stromatolites appear to have grown in a normal open marine setting (Fig. 2). The environmental stress is probably mainly caused by strong tidal currents and the resultant ooids sand-waves which periodically engulf the stromatolites.

\subsection{Implications for the Early Triassic extended environmental stress and microbial bloom}

Early Triassic stromatolites have been reported widely from around the world (Sano and Nakashima, 1997; Richoz et al., 2005; Hips and Haas, 2006; Pruss et al., 2006; Kershaw et al., 2011; Chen et al., 2012, 2014; Mata and Bottjer, 2012; Luo et al., 2016). In particular, the Permian-Triassic boundary microbialites (PTBMs) were widely distributed in low-latitude shallow-marine carbonate shelves in central Tethyan continents (Yang et al., 2011; Kershaw et al., 2012). Some biogeochemical signals mirroring various microbial communities associated with benthic microbial mats have been detected from diagenetic carbonate crystal fan deposits of Dienerian-Smithian age (Heindel et al., 2014). Thus, microbes existed widely in various niches of the post-extinction oceans. Different stages of the Early Triassic stromatolites may have different microbial compositions and cause of formation. Ezaki et al. (2012) documented an Olenekian stromatolite from South China and considered that it grew in the inhospitable anoxic/sulfidic marine conditions. In contrast, the Smithian stromatolite from the Perth Basin, Western Australia grew in an oxic condition (Chen et al., 2014). The resurgence of microbialites was throughout the Early-Middle Triassic, they were suggested to proliferate particularly in six intervals: earliest Griesbachian, late Griesbachian-early Dienerian, early Smithian, late Smithian, late Spathian, and early Anisian, respectively (Baud et al., 2005, 2007; Pruss et al., 2006; Mata and Bottjer, 2012; Chen et al., 2014; Luo et al., 2014, 2016). Of these, the PTBMs are most widespread among all Early Triassic microbialites (Kershaw et al., 2012). Copious coccoid-like objects, presumed to be cynaobacteria were found in the PTBMs from Sichuan and Guizhou Provinces, South China (Ezaki et al., 2003, 2008; Wang et al., 2005). Similar calcispheroids have also been reported from the P-Tr stromatolites in the Chongyang area, Hubei Province, South China (Yang et al., 2008, 2011) and Bükk Mountains of Hungary (Hips and Haas, 2006). The similarity in microbial composition possibly suggests a similar microbial metabolism mechanism inducing the growth of these PTBMs. However, microbialtes in other intervals of the Early Triassic preserve different microbes such as coccoid-like objects, bacterial clump-like spheroids, 'Gakhumella', and Renalcis of the earliest and late Early Triassic microbilates (Lehermann, 1999; Ezaki et al., 2003, 2008, 2012; Wang et al., 2005; Yang et al., 2008, 2011; Wu et al., 2014; Luo et al., 2016; Fang et al., 2016), filament sheaths in Smithian stromatolite (Chen et al., 2014), and fossilized filamentous cyanobacteria sheath in early Anisian (Luo et al., 2014).

The Lichuan stromatolite is interpreted to be formed from the activity of SRB or oxygenic phototrophic bacteria, whose microbial composition was largely controlled by inhospitable anoxic/sulphidic marine conditions that prevailed in the Early Triassic oceans (Ezaki et al., 2012; Huang et al., 2016). In this regard, the Lichuan stromatolite might also represent a regional sedimentary response to the microbial proliferation during 
the Smithian. The post-extinction hash environments therefore may have continued to exist or even expanded in shallow marine in South China during the Smithian (Huang et al., 2016). A few microbialites of Early Triassic age have also been reported from western US and Oman (Woods and Baud, 2008; Woods, 2009, 2014), but it is not yet clear whether these microbialite deposits have similar geobiologic features to those reported by Ezaki et al. (2012) or Chen et al. (2014). In addition, stack pattern of ooid-stromatolite complex in Lichuan is similar to those coeval deposits in Germanic basin, implying the worldwide proliferation of microbes during Early Triassic period.

\section{Conclusions}

A unique massive stromatolite, probably the known thickest Early Triassic stromatolite deposit developing in association with giant ooid banks is described from the middle Lower Triassic (late Smithian) of the Lichuan area, western Hubei Province, South China. The stromatolites are up to $18 \mathrm{~m}$ high and exhibit various growing forms including domical, stratified columnar, wavy laminated, cabbage-shaped, roll-up, and conical structures. Under the optical microscope, stromatolite laminations are conspicuous and usually consist of diffuse laminated, reticular, intraclastic, and irregular distinct clotted microstructure. The SEM imaging reveals that the common occurrence of nanometer-scale textures relative to the formation of the dolomite both in stromatolite and ooid, as well as authigenic quartz grains commonly preserving in stromatolite, could be attributed to abundant organic matters in seawater. Thick giant stromatolite provides us with invaluable insight into Early Triassic oceanic conditions. Microbes were probably extremely flourishing in both eastern and western margins of the Palaeo-Tethys Ocean during middle Early Triassic, suggesting the worldwide long-term degradation of marine ecosystems after the end-Permian extinction.

\section{Acknowledgement}

This study is partly supported by the 111 Program of China (B80210), three research grants from the State Key Laboratory of Biogeology and Environmental Geology (BGEG), and State Key Laboratory of Geological Processes and Mineral Resources, China University of Geosciences (GBL11206 and GPMR201302), and two NSFC grants (41272023, 41572091). It is a contribution to the IGCP 630 "Permian-Triassic extreme climate and environment"

\section{References}

Adachi, N., Ezaki, Y., Liu, J.B., 2004. The fabrics and origins of peloids immediately after the end-Permian extinction, Guizhou Province, South China. Sediment. Geol. $164,161-178$.

Andres, S., Miriam, T., Reid, R.P., Pamela, R.R., 2006. Growth morphologies of modern marine stromatolites: A case study from Highborne Cay, Bahamas. Sediment. Geol. 
$185,319-328$

Arvidson, R.S., and MacKenzie, F.T., 1999, The dolomite problem: Control of precipitation kinetics by temperature and saturation state. Am. J. Sci. 299, 257-288.

Baud, A., Richoz, S., Marcoux, J., 2005. Calcimicrobial cap rocks from the basal Triassic units: western Taurus occurrences (SW Turkey). Comptes Rendus Palevol 4, 501-514.

Baud, A., Richoz, S., Pruss, S., 2007. The Lower Triassic anachronistic carbonate facies in space and time. Glob. Planet. Chang. 55, 81-89.

Burne, S.J., McKenzie, J.A., Vasconcelos, C., 2000. Dolomite formation and biogeochemical cycles in the Phanerozoic. Sediment. Geol. 47, 49-61.

Chafetz, H.S., Zhang, J., 1998. Authigenic euhedral megaquartz crystals in a Quaternary dolomite. J. Sediment. Res. 68, 994-1000.

Chen, Z.Q., Benton, M.J., 2012. The timing and pattern of biotic recovery following the end-Permian mass extinction. Nat. Geosci. 5, 375-383.

Chen, Z.Q., Wang, Y.B., Kershaw, S., Luo. M., Yang, H., Zhao, L.S., Fang, Y.H., Chen, J.B., Li, Yang., Zhang, L., 2014. Early Triassic stromatolites in a siliciclastic nearshore setting in northern Perth Basin, Western Australia: geobiologic features and implications for post-extinction microbial proliferation. Glob. Planet. Chang. 121, 89-100.

Dravis, J.J., 1983. Hardened subtidal stromatolites, Bahamas. Science 219, 385-386.

Erwin, D.H., 2006. Extinction: How Life on Earth Nearly Ended 250 Million Years Ago. Princeton University Press, Princeton, pp. 1-296.

Ezaki, Y.,Liu, J.B.,Adachi, N., 2003. Earliest Triassic microbialite micro- to megastructures in the Huaying area of Sichuan Province, South China: implications for the nature of oceanic conditions after the end-Permian extinction. PALAIOS 18, $388-402$.

Ezaki, Y., Liu, J.B., Adachi, N., 2012. Lower Triassic stromatolites in Luodian County, Guizhou Province, South China: evidence for the protracted devastation of the marine environments. Geobiology 10, 48-59.

Feng, Z.Z., Bao, Z.D., Li, S.W., 1997. Lithofacies Paleogeography of Early and Middle Triassic of South China. Petroleum Industry Press, Beijing, pp. 1-222 (in Chinese). Friedman, G.M., Shukla, V., 1980. Significance of Authigenic Quartz Euhedra After 
Sulfates: Example From the Lockport Formation (Middle Silurian) of New York. J. Sediment. Res. 50. 1299-1304.

Garrett, P., 1970. Phanerozoic stromatolites: noncompetetive ecologic restriction by grazing and burrowing animals. Science 169, 171-173.

Gournay, J.P., Kirklan, B.L., Folk, R.L., Lynch, F.L., 1999. Nanometer-scale features in dolomite from Pennsylvanian rocks, Paradox Basin, Utah. Sediment. Geol. 126, 243-252.

Kershaw, S., Crasquin, S., Forel, M.B., Randon, S., Collin, P.Y., Kosun, E., Richoz, S., Baud, A., 2011. Earliest Triassic microbialites in Çürük Dag, southern Turkey: composition, sequence and controls on formation. Sedimentol. 58, 739-755.

Kershaw, S., Crasquin, S., Li, Y., Collin, P.Y., Forel, M.B., Mu, X.N., Baud, A., Wang, Y., Xie, S.C., Maurer, F., Gou, L., 2012. Microbialites and global environmental change across the Permian-Triassic boundary: a synthesis. Geobiology 10, 25-47.

Li, F., Yan, J. X., Algeo, T., Wu, X., 2013. Paleoceanographic conditions following the end-Permian mass extinction recorded by giant ooids (Moyang, South China). Glob. Planet. Chang. 105, 102-120.

Li, F., Yan, J., Chen, Z.-Q., Ogg, J. G., Tian, L., Korngreen, D., Liu, K., Ma, Z., and Woods, A. D., 2015, Global oolite deposits across the Permian-Triassic boundary: A synthesis and implications for palaeoceanography immediately after the end-Permian biocrisis. Earth-Sci. Rev. 149, 163-180.

Luo, M., Chen, Z.Q., Zhao, L.S., Kershaw, S., Huang, J.Y., Wu, L.L., Yang, H., Fang, Y.H., Huang, Y.G., Zhang, Q.Y., Hu, S.X., Zhou, C.Y., Wen, W., Jia, Z.H., 2014. Early Middle Triassic stromatolites from the Luoping area, Yunnan Province, Southwest China: geobiologic features and environmental implications. Palaeogeogr. Palaeoclimatol. Palaeoecol. 412, 124-140.

Luo, M., Chen, Z.Q., Shi, G.R., Fang, Y.H., Song, H.J., Jia, Z.H., Huang, Y.G., Hao, Y., 2016. Upper Lower Triassic stromatolite from Anhui, South China: geobiologic features and palaeoenvironmental implications. Palaeogeogr. Palaeoclimatol. Palaeoecol. 452, 40-54.

Mata, S.A., Bottjer, D.J., 2012. Microbes and mass extinctions: paleoenvironmental distribution of microbialites during times of biotic crisis. Geobiology 10, 3-24. 
Mei, M.X., 2008. Implication for the unusual giant oolites of the Phanerozoic and their morphological diversity: a case study from the Triassic Daye Formation at the Lichuan Section in Hubei Province. South China. Geosci. 22, 683-698 (In Chinese with English abstract).

Morse J. W., Millero F. J., Thurmond V., Brown E., and Ostlund H. G. (1984) The chemistry of Grand Bahama Bank waters: After 18 years another look. J. Geophys. Res. Oceans 89, 3604-3614.

Payne, J.L., Lehrmann, D.J., Wei, J., Knoll, A.H., 2006. The pattern and timing of biotic recovery from the end-Permian extinction on the Great Bank of Guizhou, Guizhou Province, China. PALAIOS 21, 63-85.

Pruss, S.B., Bottjer, D.J., Corsetti, F.A., Baud, A., 2006. A global marine sedimentary response to the end-Permian mass extinction: examples from southern Turkey and the western United States. Earth-Sci. Rev. 78, 193-206.

Harwood, C.L., Sumner, D.Y., 2012. Origins of microbial microstructures in the Neoproterozoic Beck Spring Dolomite: variations in microbial community and timing of lithification. J. Sediment. Res. 82, 709-722.

Heindel, K.,Richoz, S.,Birgel, D.,Brandner, R.,Klugel, A.,Krystyn, L.,Baud, A.,Horacek, M., Mohtat, T.,Peckmann, J., 2014. Biogeochemical formation of calyx-shaped carbonate crystal fans in the subsurface of the Early Triassic seafloor. Gondwana Res. http:// dx.doi.org/10.1016/j.gr.2013.11.004.

Heller, P.L., Komar, P.D., Pevear, D.R., 1980. Transport processes in ooid genesis. J. Sediment. Res. 50, 943-951.

Hips, K., Haas, J., 2006. Calcimicrobial stromatolites at the Permian-Triassic boundary in a western Tethyan section, Bükk Mountains, Hungary. Sediment. Geol. 185, 239-253.

Noffke, N., Gerdes, G., Klenke, Th., 2003. Benthic cyanobacteria and their influence on the sedimentary dynamics of peritidal depositional systems (siliciclastic, evaporitic salty and evaporitic carbonatic). Earth-Sci. Rev. 12, 1-14.

Richoz, S., Baud, A., Krystyn, L., Twitchett, R., Marcoux, J., 2005. Permo-Triassic deposits of the Oman Mountains: from basin and slope to the shallow platform. Field guidebook. 24th IAS Regional Meeting, Oman. 
Saito, R., Kaiho, K., Oba, M., Fujibayashi, M., Tong, J.N., Tian, L., 2015. Predominance of Archaea-derived hydrocarbons in an Early Triassic microbialite. Org. Geochem. 85, 66-75.

Sano, H., Nakashima, K., 1997. Lowermost Triassic (Griesbachian) microbial bindstone-cementstone facies southwest Japan. Facies 36, 1-24.

Shapiro, R.S., 2000. A comment on the systematic confusion of thrombolites. PALAIOS $15,166-169$.

Song, H.J., Wignall, P.B., Tong, J.N., Bond, D.P.G., Song, H.Y., Lai, X.L., Zhang, K.X., Wang, H.M., Chen, Y.L., 2012. Geochemical evidence from bio-apatite for multiple oceanic anoxic events during Permian-Triassic transition and the link with end-Permian extinction and recovery. Earth Planet. Sci. Lett. 353-354, 12-21.

Sumner, D.Y., Grotzinger, J.P., 1993. Numerical modeling of ooid size and the problem of Neoproterozoic giant ooids. J. Sediment. Res. 63, 974-982.

Suosaari, E.P., Reid, R.P., Playford, P.E., Foster, J.S., Stolz, J.F., Casaburi, G., Hagan, P.D., Chirayath, V., Macintyre, I.G., Planavsky, N.J. Eberli, G.P., 2016. New multi-scale perspectives on the stromatolites of Shark Bay, Western Australia. Sci. Rep. 6, 1-13.

Vasconcelos, C.O., McKenzie, J.A., 1997. Microbial mediation of modern dolomite precipitation and diagenesis under anoxic conditions (Lagoa Vermelha, Rio de Janeiro, Brazil). J. Sediment. Res. 67, 378-390.

Wang, Y.B., Tong, J.N., Wang, J.S., Zhou, X.G., 2005. Calcimicrobialite after end-Permian mass extinction in South China and its palaeoenvironmental significance. Chin. Sci. Bull. 50, 7665-7671.

Wang, Z.H., Cao, Y.Y., 1981. Early Triassic conodonts from Lichuan, western Hubei. Acta Palaeontol. Sin. 20.363-375 (In Chinese with English abstract).

Warthmann, R., van Lith, Y., Vasconcelos, C., McKenzie, J.A., Karpoff, A.-M., 2000. Bacterially induced dolomite precipitation in anoxic culture experiments. Geology 28, 1091-1094.

Woods, A.D., Baud, A., 2008. Anachronistic facies from a drowned Lower Triassic carbonate platform: lower member of the Alwa Formation (Ba'id Exotic), Oman Mountains. Sediment. Geol. 209, 1-14. 
Woods, A.D., 2009. Anatomy of an anachronistic carbonate platform: Lower Triassic carbonates of the southwestern United States. Aust. J. Earth Sci. 56, 825-839.

Woods, A.D., 2014. Assessing Early Triassic paleoceanographic conditions via unusual sedimentary fabrics and features. Earth-Sci. Rev. 137, 6-18.

Wu, Y.L., Zhu, H.F., Zhu, Z.F., Yan, Y.J., 1994. Triassic Lithofacies, Paleogeography and Mineralization in South China. Geological Publishing House, Beijing. 28 pp. (in Chinese with English abstract).

Yang, H., Wang, Y.B., Chen, L., 2008. Occurrence of organic matter in calcimicrobialites across Permian-Triassic boundary in Huayingshan region, Sichuan, South China. J. China Univ. Geosci. 19, 518-525.

Yang, H., Chen, Z.Q., Wang, Y.B., Tong, J.N., Song, H.J., Chen, J., 2011. Composition and structure of microbialite ecosystems following the end-Permian mass extinction in South China. Palaeogeogr. Palaeoclimatol. Palaeoecol. 308, 111-128.

Yin, H.F., Huang, S.J., Zhang, K.X., 1992. The effects of volcanism on the Permo-Triassic mass extinction in South China. In: Sweet, W.C., Yang, Z.Y., Dickins, J.M., Yin, H.F. (Eds), Permo-Triassic Events in the Eastern Tethys. Cambridge University Press, London, pp. 146-157.

Zhao, L.S., Chen, Y.L., Chen, Z.Q., Gao, L., 2013. Uppermost Permian to Lower Triassic conodont zonation from Three Georges area, South China. PALAIOS 28, 523-540.

Zhao, L.S., Orchard, M.J., Tong, J.N., Sun, Z.M., Zuo, J.X., Zhang, S.X., Yun, A.L., 2007. Lower Triassic conodont sequence in Chaohu, Anhui Province, China and its global correlation. Palaeogeogr. Palaeoclimatol. Palaeoecol. 252, 24-38.

\section{Figure captions}

Fig. 1. Location of the Lichuan section in the Lichuan City, western Hubei Province. South China.

Fig. 2. Early Triassic palaeogeographic configurations of the upper Yangtze region (modified from Wu et al., 1994). Transect from A to D indicates an eastward progradational process. The original conodont zones follow Wang et al. (1981), and modified based on those established from the uppermost Permian to Lower Triassic of 
the neighboring Daxiakou section (Zhao et al., 2013). The stromatolite-oolite complex developed in Smithian. Roman numerals represent different sedimentary facies:I, swamp/fluvial facies; II, tidal-flat facies; III, lagoon facies; IV, tidal-flat facies; V, oolitic beach; VI, ramp facies; VII, basin facies.

Fig. 3. Lithostratigraphy of the upper Daye Formation and the lower Jialingjiang Formation at the Lichuan section. Conodont zones follow Wang et al. (1981).

Fig. 4. Field photos of the Daxiandong section. A, Well-exposed successions of the upper Daye Formation and lower Jialingjiang Formation. The person in the center is 1.6 meter high. Stromatolites have been slicing by vertical plane. B-C, Vertical sections of stromatolite in the middle beddings, show domical structure. Domical stromatolites are closely packed. D, Vertical sections of stromatolite in the middle beddings, shows upward growth morphology and seemingly branching of a single stromatolite dome. E, Vertical sections of stromatolite in the Upper part and the top of the domical stromatolite (Dom) was eroded and surrounded by oolitic sands (OS). Stromatolite was destructed and the fragments were re-deposited aside the stromatolite column (arrows indicate the boundary of domical stromatolite and oolitic sands). Color in D, F is processed by Adobe Photoshop CS6.

Fig. 5. Field photos showing macro-structures of the stromatilite. A, Wavy laminated stromatolite shown on the vertical dimension. B, Vertical section of cabbage-shaped stromatolite. C, Field view showing laminated and roll-up structures of stromatolite. D, Vertical section of stromatolite showing lateral extension feature. E, Domical stromatolite showing distinct laminae. F, Sharply peaked conical forms stromatolite in vertical section.

Fig. 6. Photomicrographs of the Lichuan cabbage-shaped stromatolite, plane-polarized light. A, Transmitted photo of stromatolite laminae on vertical profile. Note the dark colored diffusive laminae alternating with light colored laminae, and dark colored diffusive laminae are wavy and clotted in some part. B, Close-up of boxed area on the upper left in A, showing reticular microstructures in lamina. C, Closed-up of boxed are in B showing detailed reticular microstructures, which made up of micrite or opaque materials.

Fig. 7. Photomicrographs of the Lichuan stromatolite, plane-polarized light. A-B, 
different scale of reticular microstructures. A, There is intergradation between dark laminated/reticular structures and light colored sparry clacite, highlighted by deep red color. Color is processed by Adobe Photoshop CS6. B, Reticular microstructures showing arc-shaped or forming semi-circle and constructing chamber-like structures. C-D, Intraclastic microstructure. The honey colored sparry dolomite forming irregular intraclasts. Noted the poor roundness and in some place, edge of intraclasts is sharp. Matrix shows vein-like shape. E, Irregular distinct clotted microstructures. Individual dark rounded microclots are densely spaced. F, Enlargement of distinct clots. Individual dark rounded microclots are visible at the outer margin mesoclotes where they are less densely packed.

Fig. 8. Thin section photomicrograph and SEM photomicrographs of Lichuan stromatolie. A, Plane-polarized transmitted light showing intraclastic microstructure $(\mathrm{dol}=$ dolomite). B, BSE image of the same area in A. Darker area shows dolomite clumps. C, Distributions of magnesium of the same area in B. D, Micro-quartz crystal within stromatolite laminae. Note the platy clay minerals (arrows) are enwrapped within micro-quartz grains. E, Enlargement of the dolomite crystals surface in B. Note the surface of the dolomite has irregular to curdled texture. F, Nano-scale surface structure of the dolomite in E. Lumpy-shaped (arrow) nanometer-scale textures.

Fig. 9. Field photographs of ooids at Lichuan section. A, Samples from the field of the lowest bed 7 show thin laminae and ooids laminations. B, Oolitic grainstone composed of giant ooids (orange arrow) with locally oolite intraclasts (red arrow). The sample was etched by diluted hydrochloric acid. C, Weathering surface of oolitic grainstone from the bed 2.

Fig. 10. Photomicrographs of ooids at Lichuan section, plane-polarized light. A, Ooids show fine psephicity but relatively poor sorting. B-C, Giant ooids displaying concentric laminae, recrystallized (dolomite-spar) nuclei (B). Note giant ooids with selectively dolomitization laminae (arrow). D, Fragmentized ooids with outer sealed cortices. E-F, Compound ooids. Smaller ooids and other grains are frequently cemented together to form aggregate grains that may be bound together by laminated micrite.

Fig. 11. Thin section photomicrograph of sample in figure 9A, plane-polarized light. 
Ooids layers alternate with relatively dark layers. Dark layers between two ooids layers are characterized by their stratified feature, similar to those in stromatolites. Note that the distinct dark and light colored laminae in the middle. Ooids in the lower part of the thin section are notable by their "ghost" texture, probable resulting from dissolution during diagenesis. Ooids in the upper part are relatively well-preserved. Note the erosion of dark laminae by ooids (arrow).

Fig. 12. Ooids in plane-polarized transmitted light $(\mathrm{A}-\mathrm{C})$ and different wavelengths of fluorescent light under different exciting light (A1-C1, A2-C2, A3-C3). Blue fluorescence (A1-C1, wavelength of 460-490 nm) is excited by exciting light that has wavelength ranging from $330 \mathrm{~nm}$ to $380 \mathrm{~nm}$; Green to light yellow fluorescence (A2-C2, wavelength $510-540 \mathrm{~nm}$ ) is excited by exciting light that has wavelength ranging from $450 \mathrm{~nm}$ to $490 \mathrm{~nm}$; Red fluorescence (A3-C3, wavelength $630 \mathrm{~nm}-660$ $\mathrm{nm}$ ) is excited by exciting light that has wavelength of 510-560 nm. Note that dark laminae in all ooids samples are all actively responding to exciting light, while coarse-grained dolomite or calcite cement is poorly responded to fluorescent light.

Fig. 13. SEM photomicrographs highlighting microbial fabric and authigenic mineral in giant-ooid cortices. A, Fresh broken surface showing microstructures of ooids. The ooids are rimmed by a short bladed cement phase (BL) and the pore space is commonly occluded by blocky calcite cement (BC). B, Polished surface eroded by iluted hydrochloric acid, showing ooids cortices and outer bladed cement (BL) and blocky calcite cement (BC). C, Ooid with sparry dolomite nuclei. D, Enlargement of the dolomite nuclei. Note the contact between dolomite and outer calcite is sharp. E, Enlargement of the contact area. Note the surface of the dolomite has irregular to curdled texture. F, Nano scale of surface of the dolomite in E. Note numerous isolated rod-shaped and lumpy-shaped (arrow) nanometer-scale textures.

Fig. 14. Cartoon diagram showing growth and demise of the Lichuan stromatolite and oolite in Smithian, corresponding to figure 2D. Stage (A): the Lichuan area was above the fair weather wave base, and ooids started to growth. Stage (B): stromatolites initiated on ooids or directly on soft sediment. Stromatolites are densely placed and closely piled up. Environmental factors are probably the main reason for the thriving of stromatolite. Stage (C): ooids developed on the top of the stromatolite. Stromatolites 
752 ceased growth due to high energy conditions and erosion of stromatolite appeared.

753 Stage (D): Again, reoccurrence of environmental factors in favoring of stromatolite

754 growth. Thickness of stromatolites in this horizon is thinner than the former one. Stage

755 (E): ooids developed on the top of the stromatolite similar to stage C. 
782 Figure 1

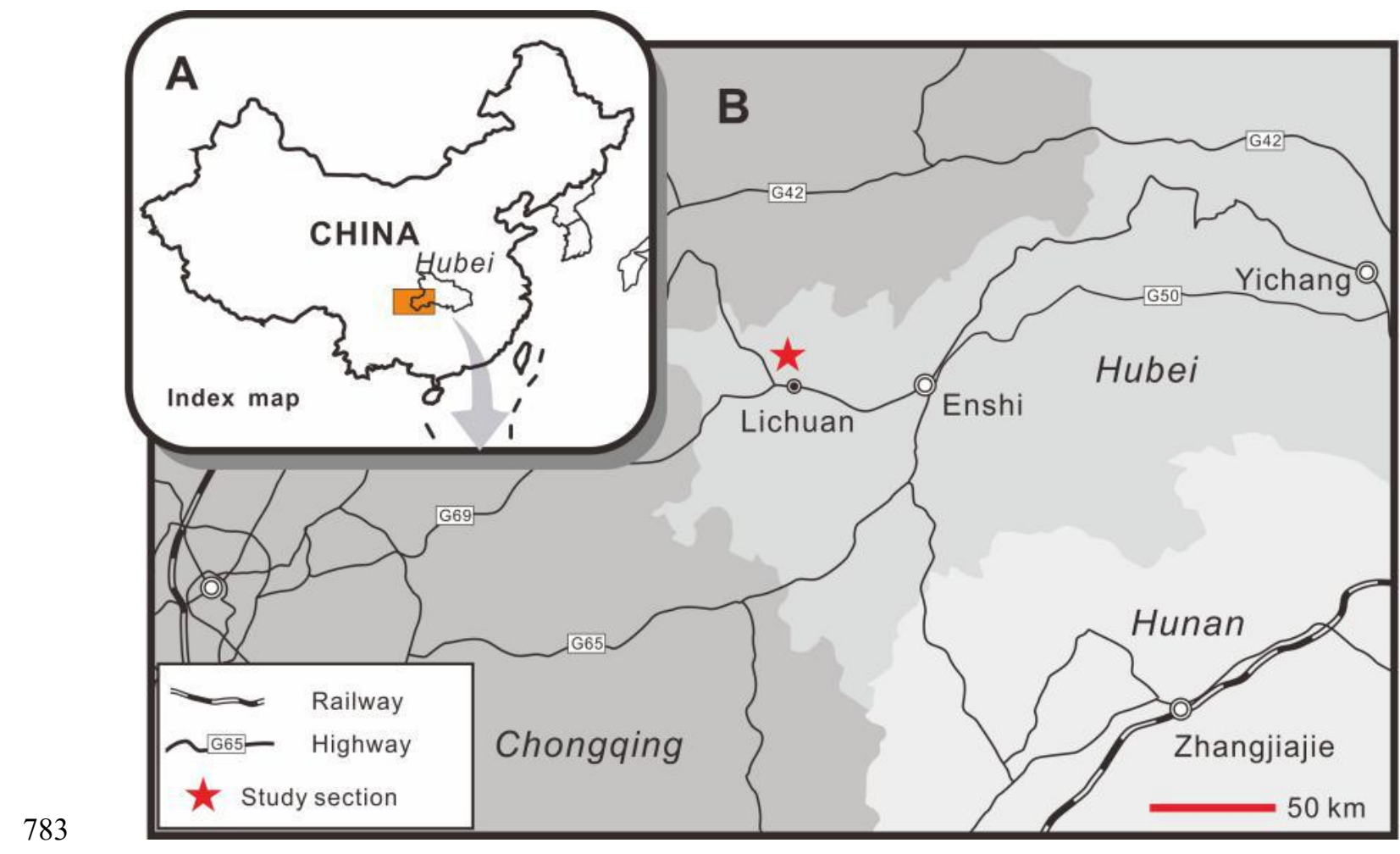

784

785

786 Figure 2
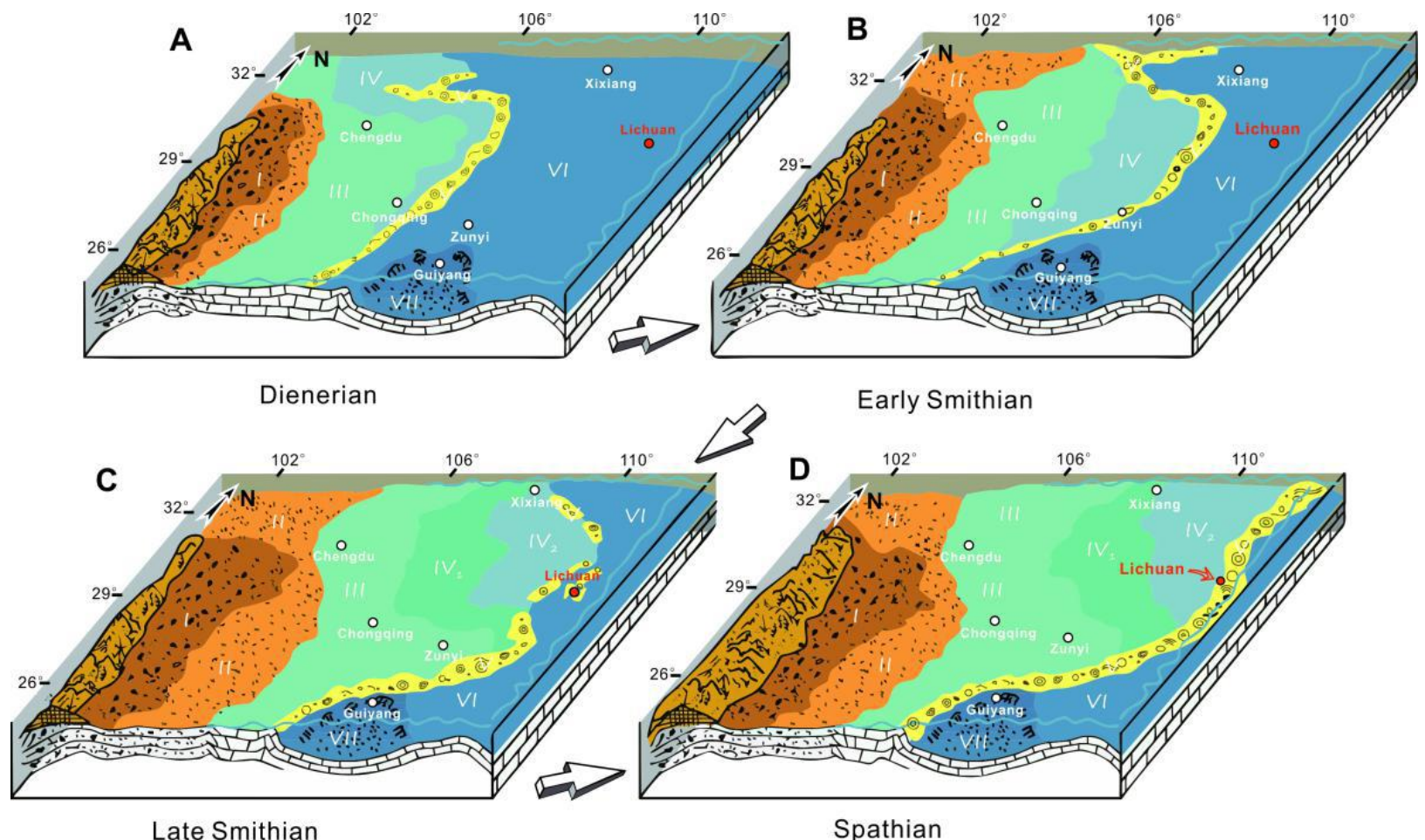
$788 \quad$ Figure 3

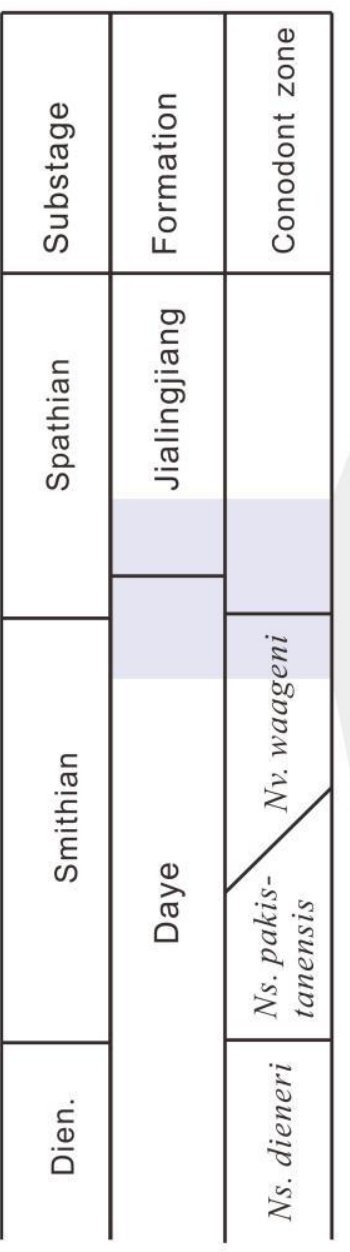
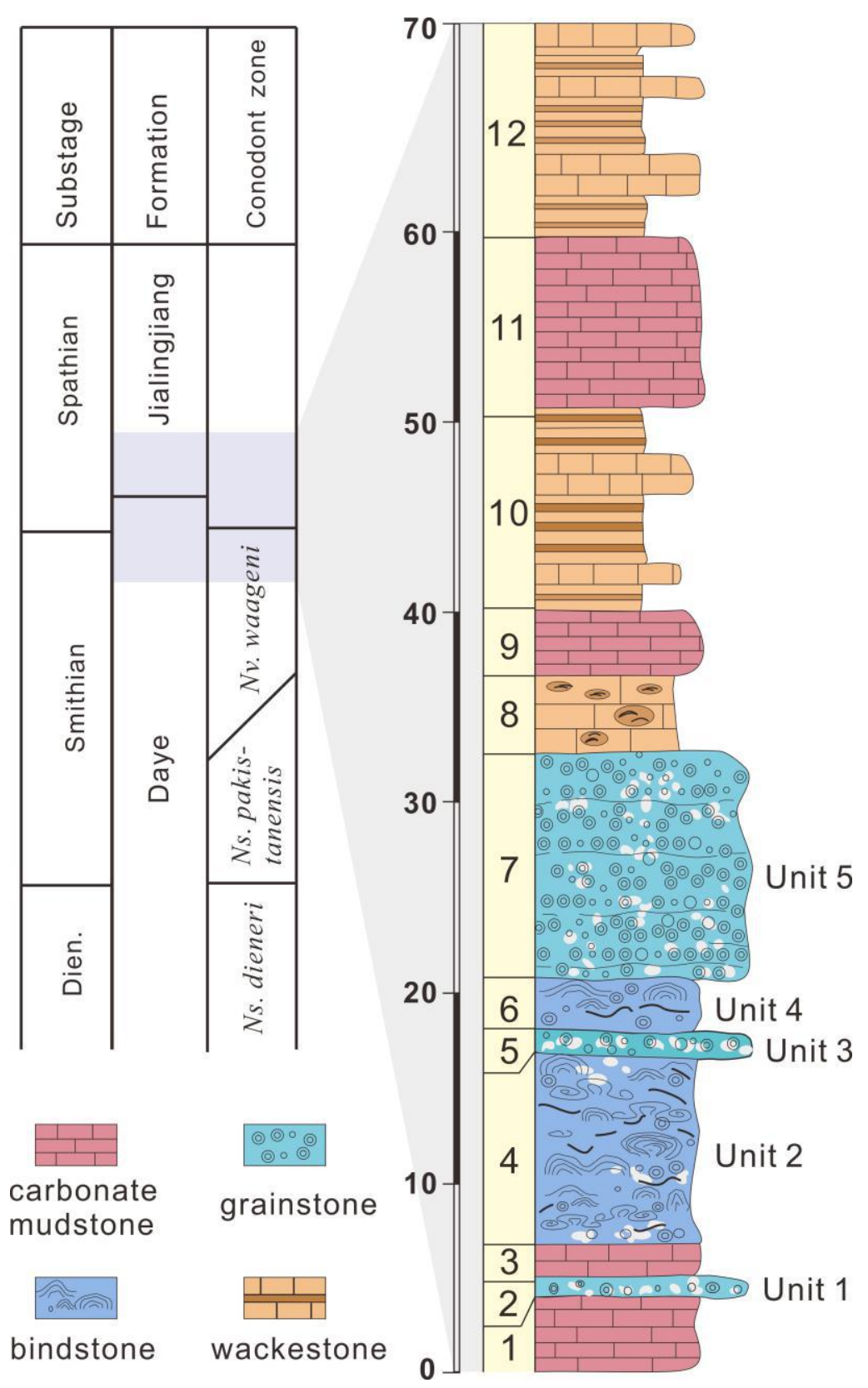

carbonate mudstone

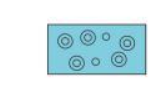
grainstone
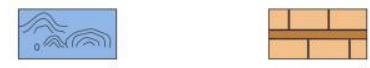

bindstone wackestone

790

791

792

793

794

795

796 
$797 \quad$ Figure 4
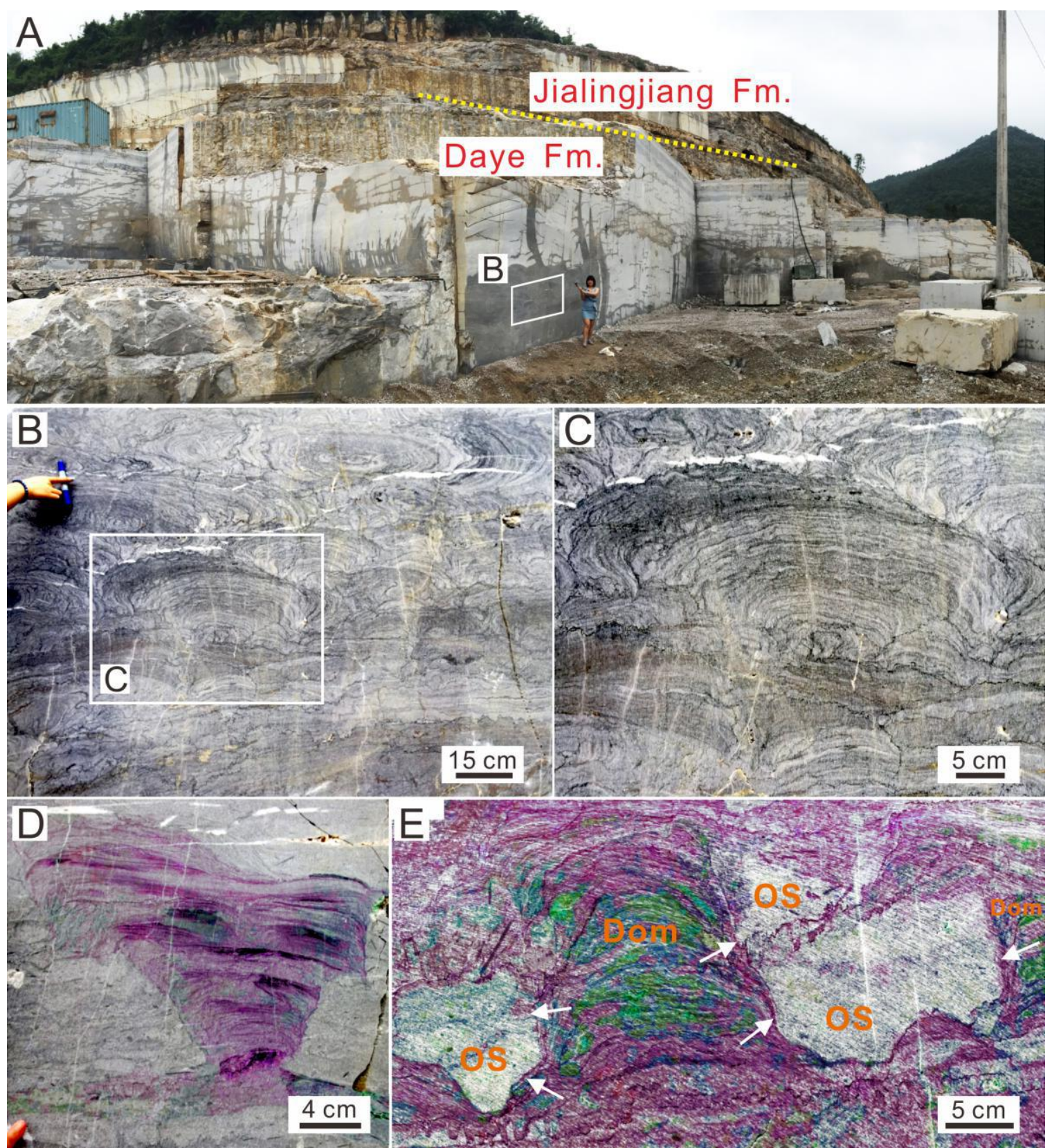

799

800

801

802

803

804 
Figure 5
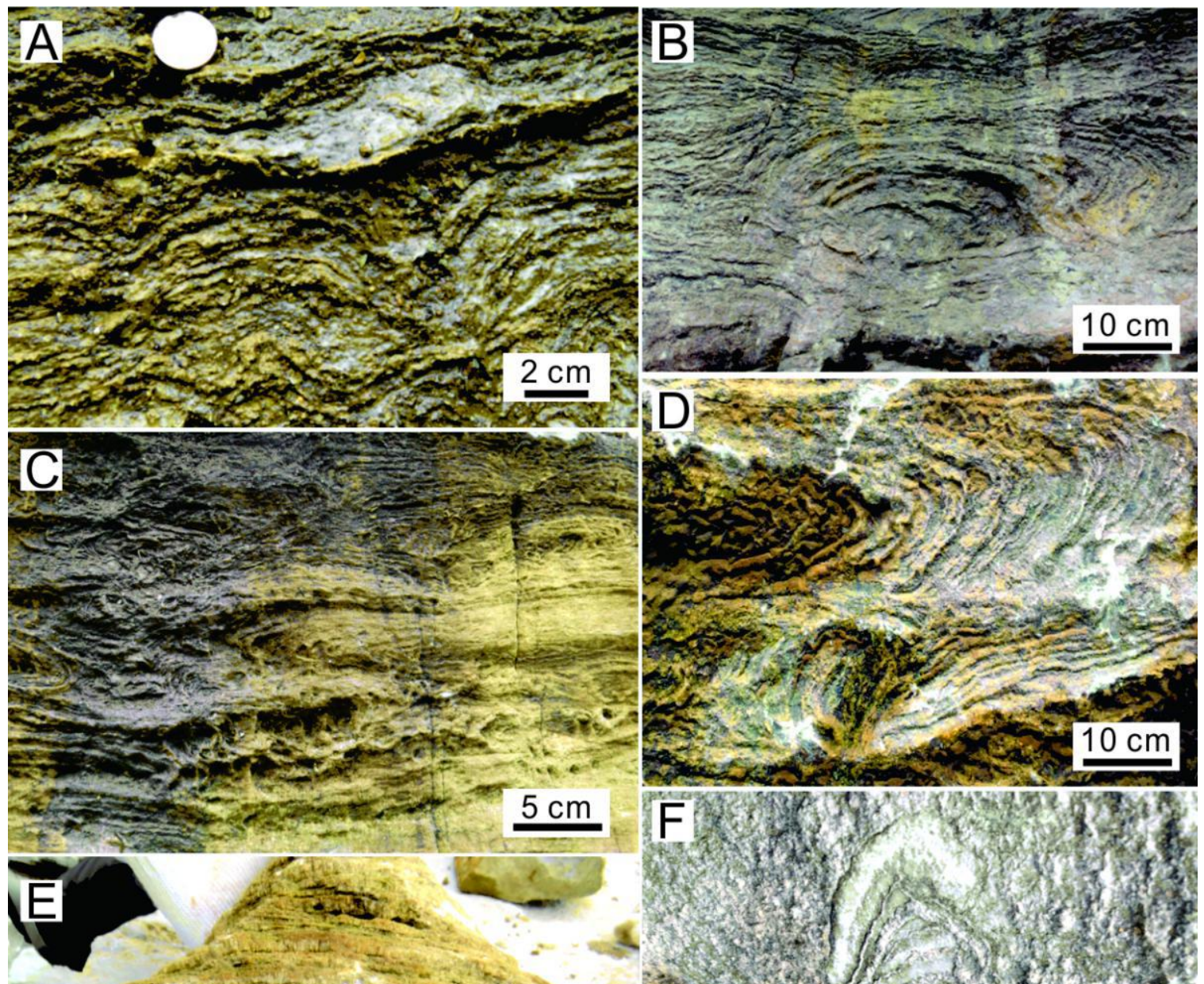

3.
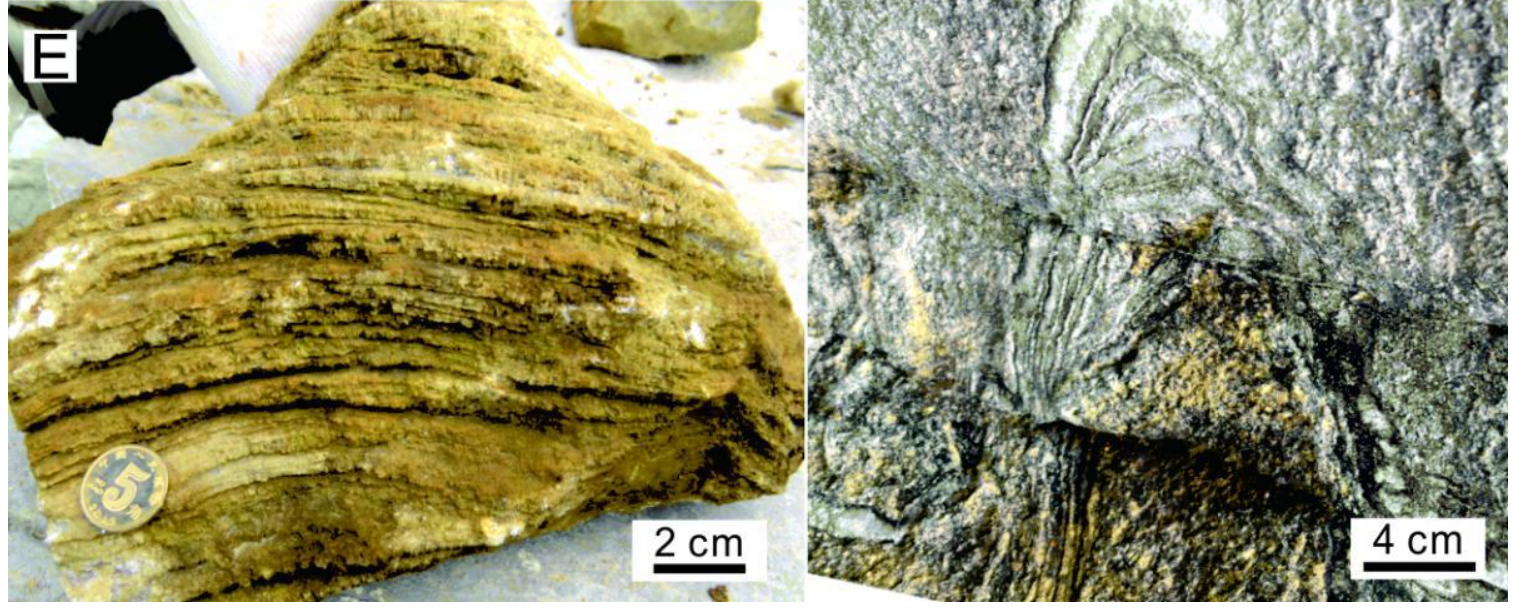

808

809

810

811

812

813

814 
815 Figure 6

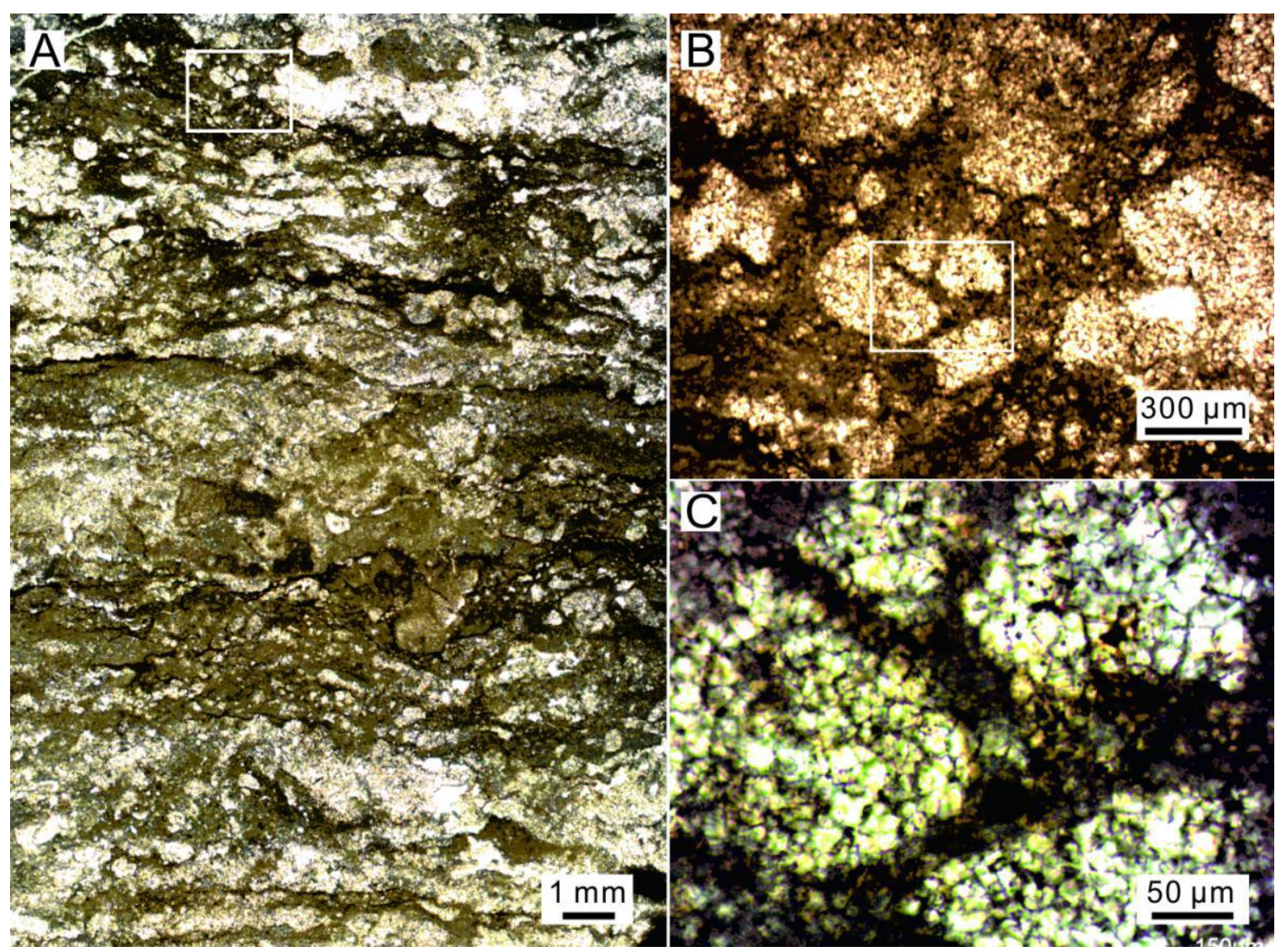

817

818

819

820

821

822

823

824

825

826

827

828

829

830 


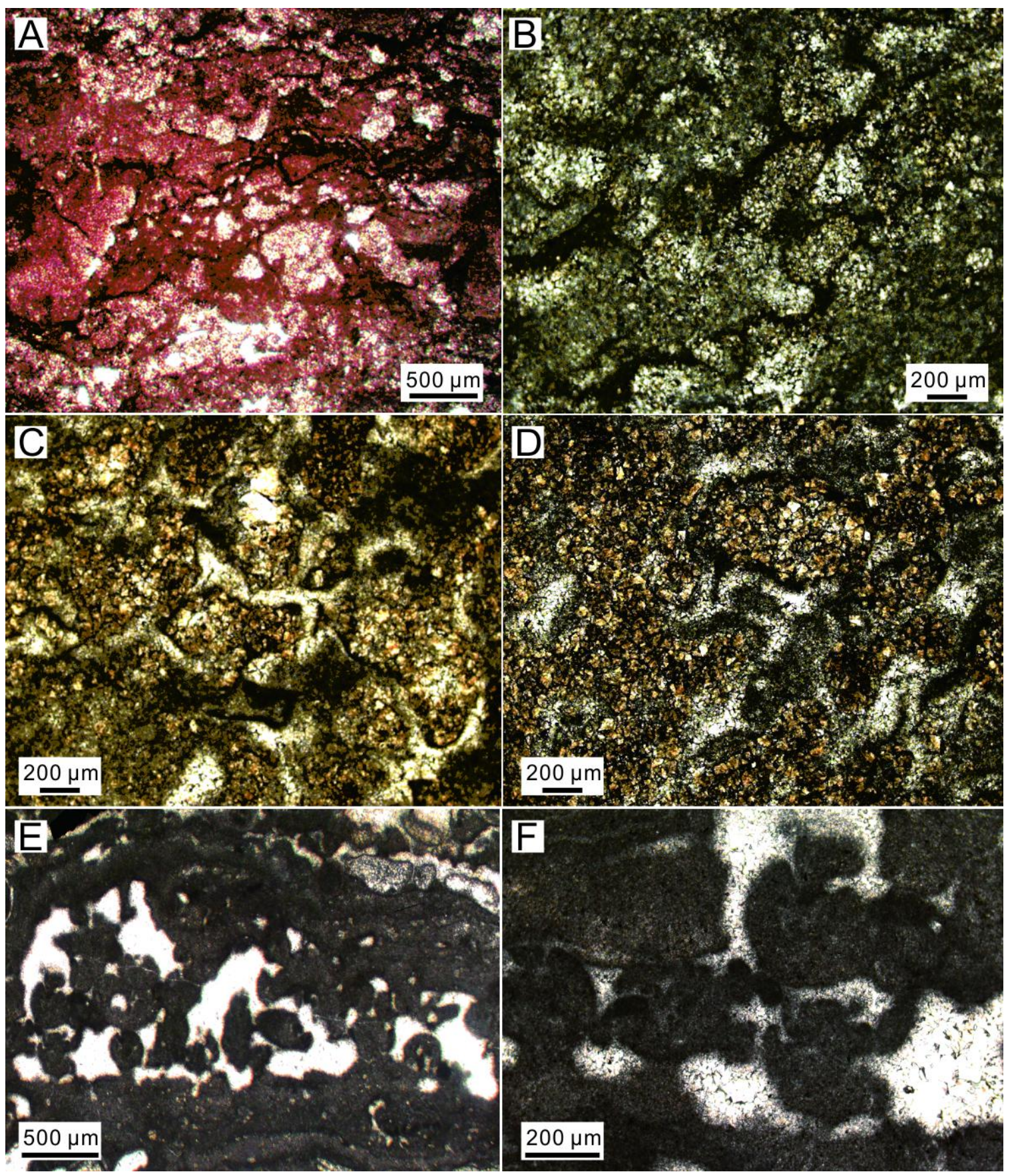


$839 \quad$ Figure 8
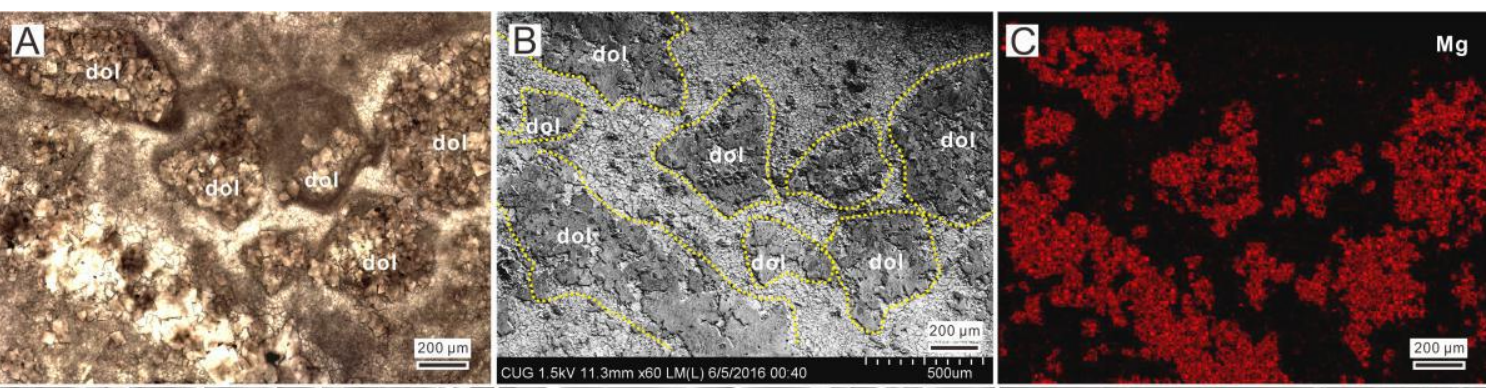

840
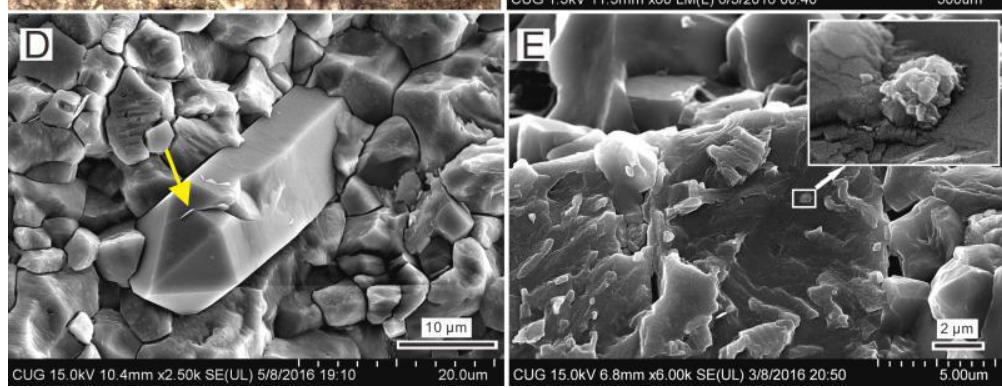

F

841

842

843

844

845

846

847

848

849

850

851

852

853

854

855

856

857

858

859 
$860 \quad$ Figure 9
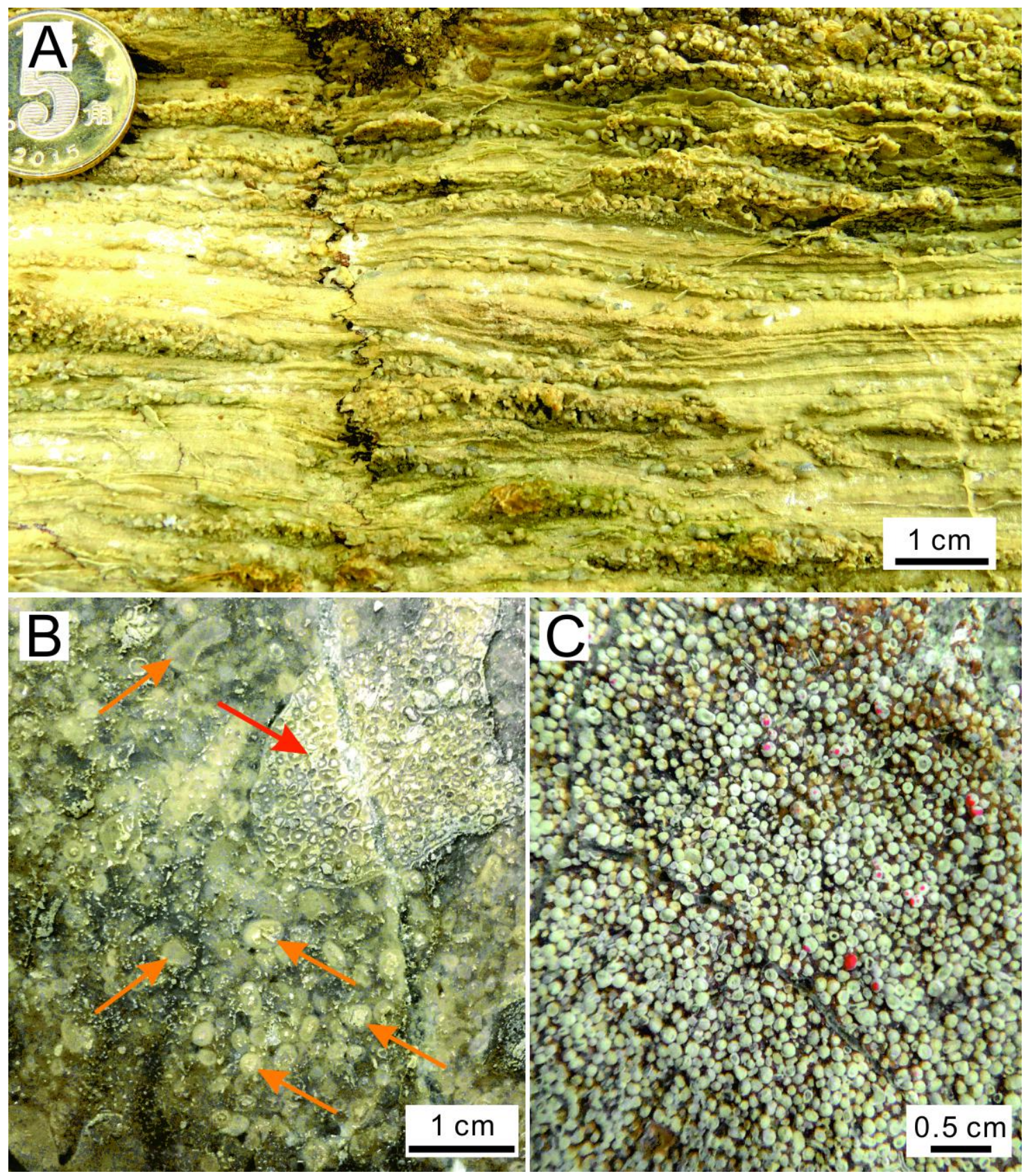

862

863

864

865

866

867 
868 Figure 10

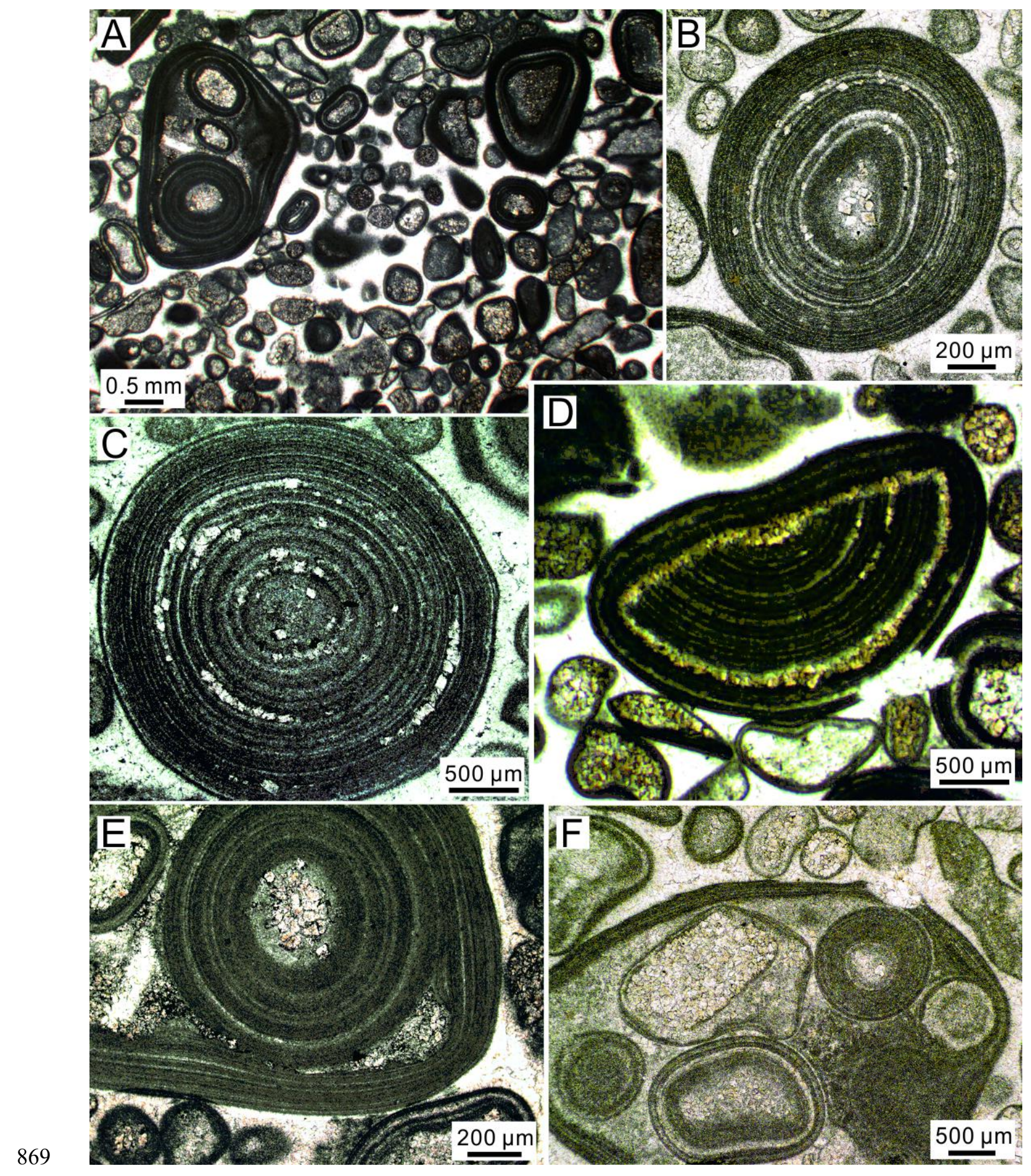


$874 \quad$ Figure 11

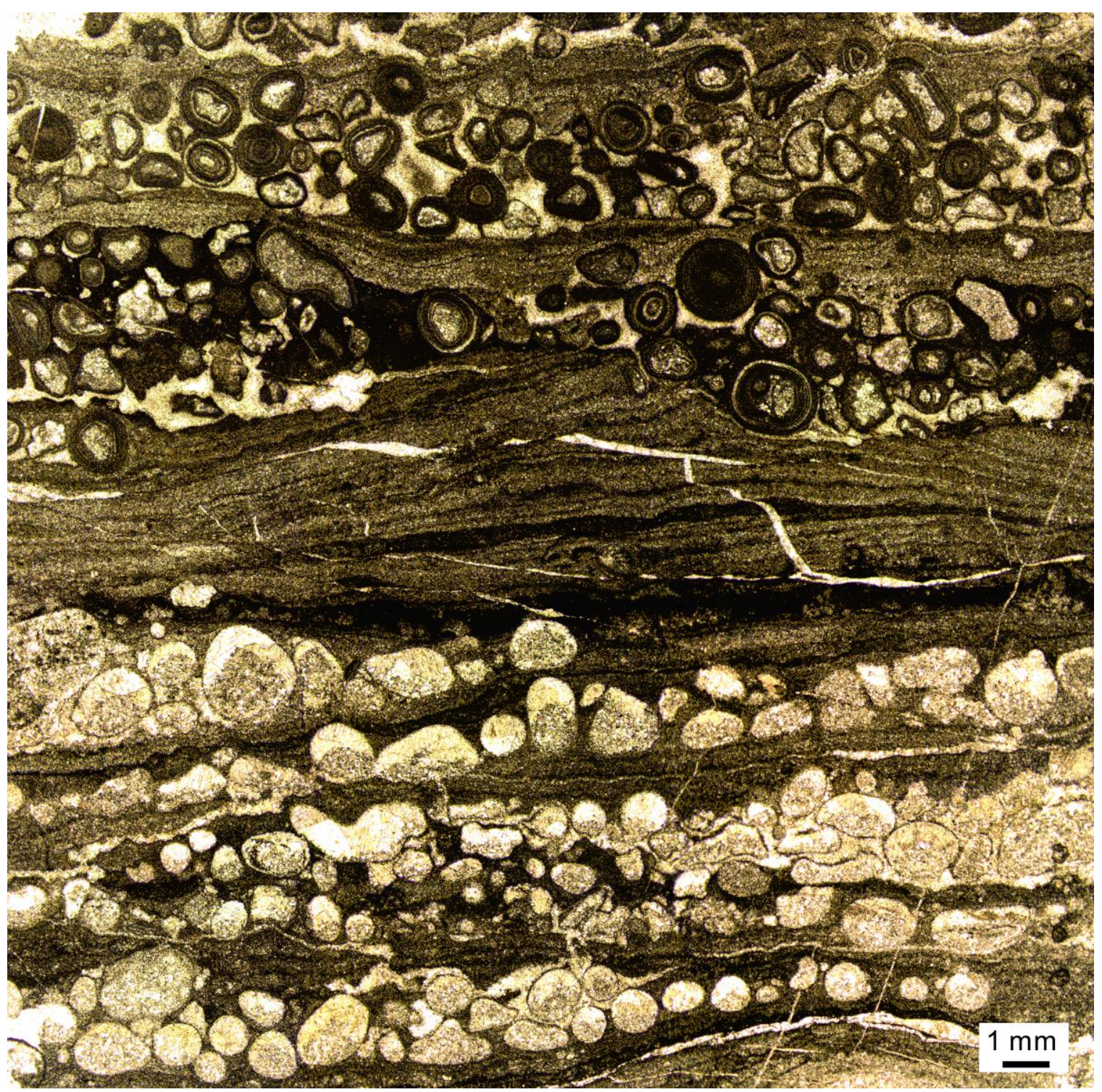

875

876

877

878

879

880

881

882

883

884 
$885 \quad$ Figure 12

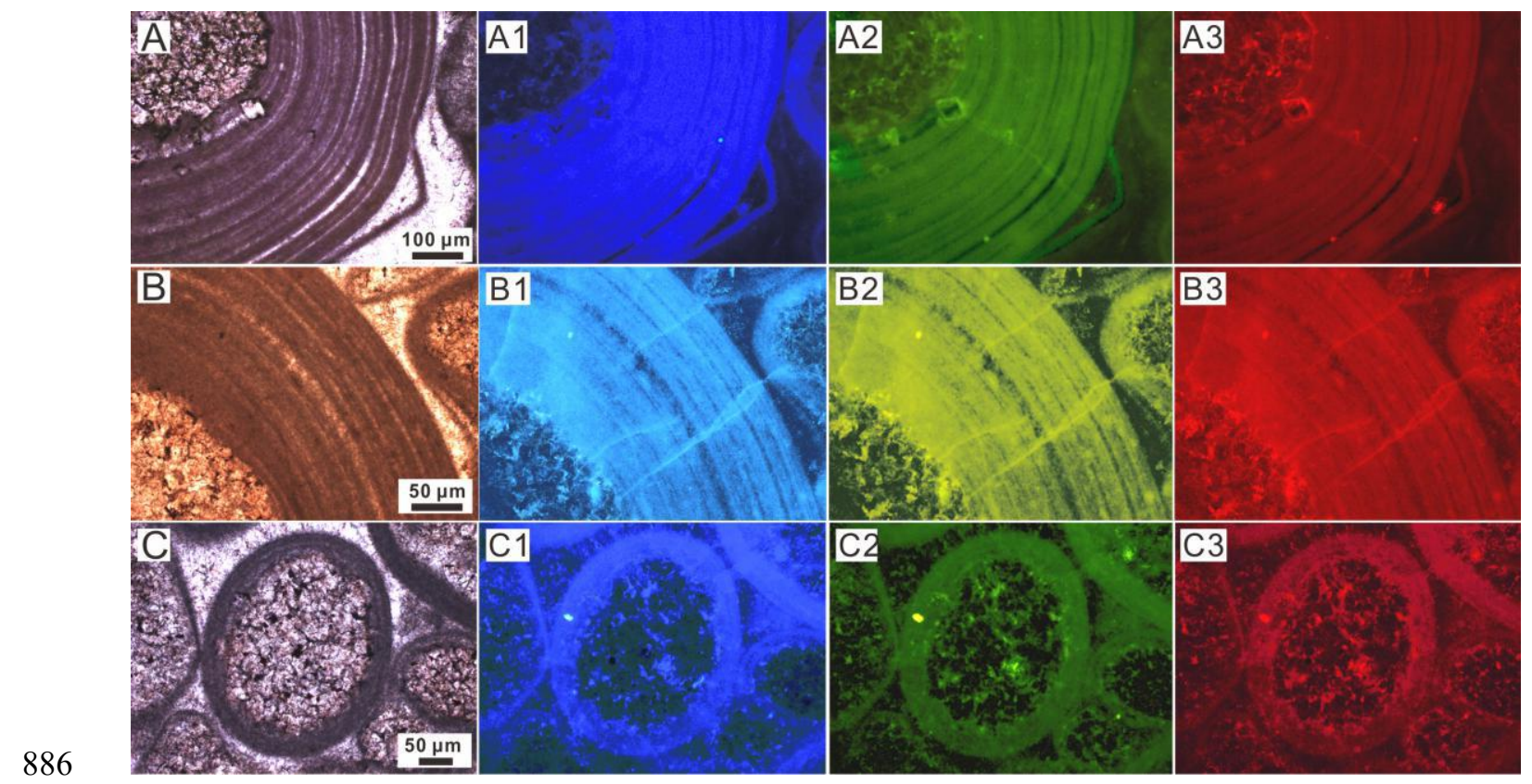

887

888

889

890

891

892

893

894

895

896

897

898

899

900

901

902

903

904 

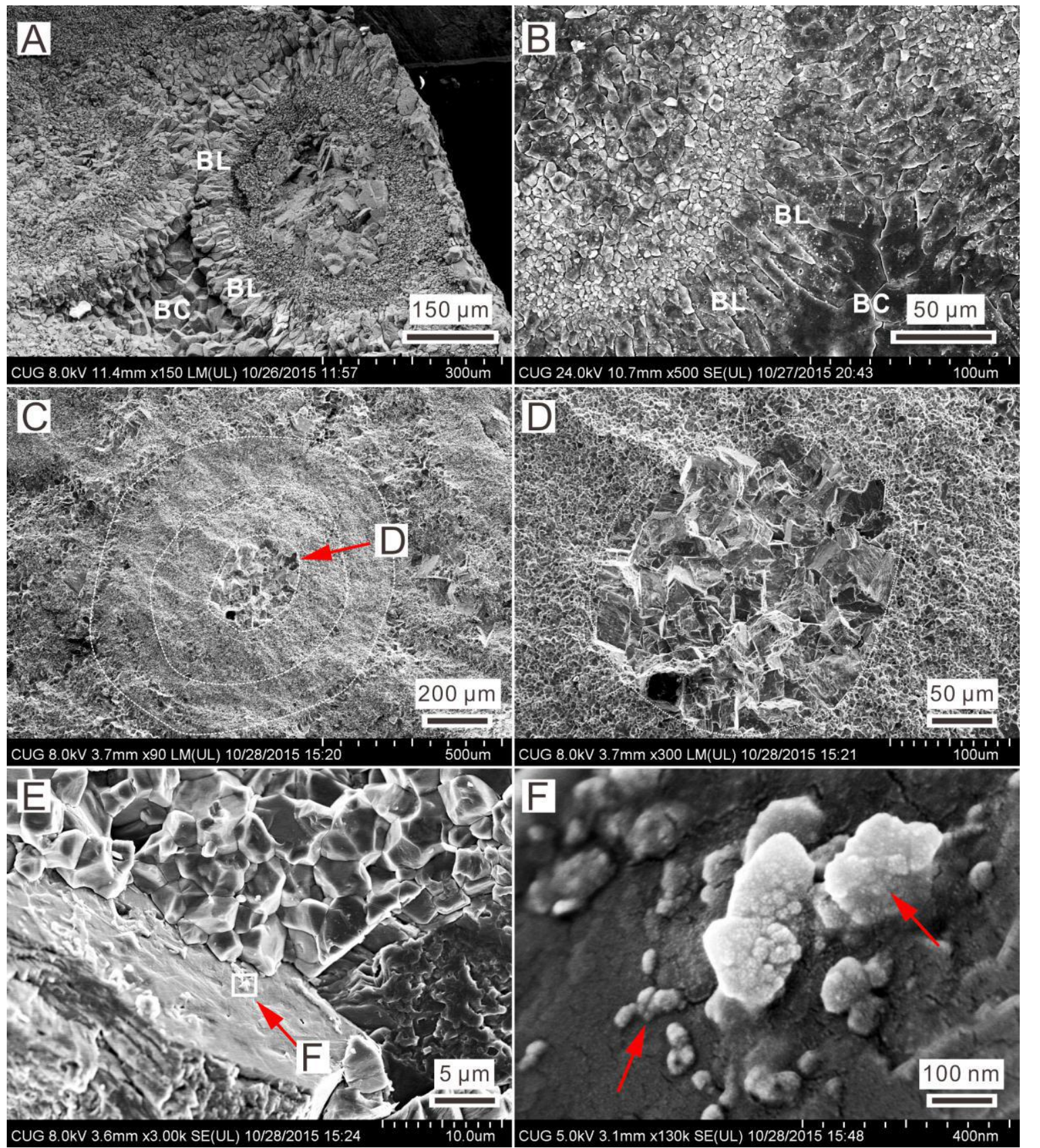

906

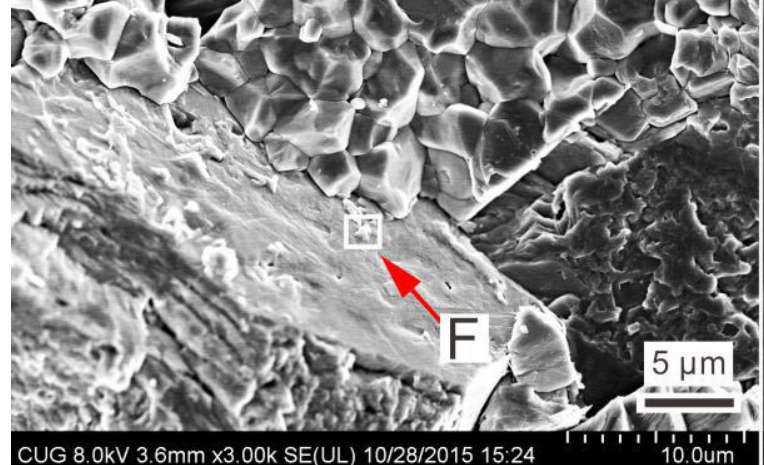

907

908

909

910

911

912 


\section{$913 \quad$ Figure 14}
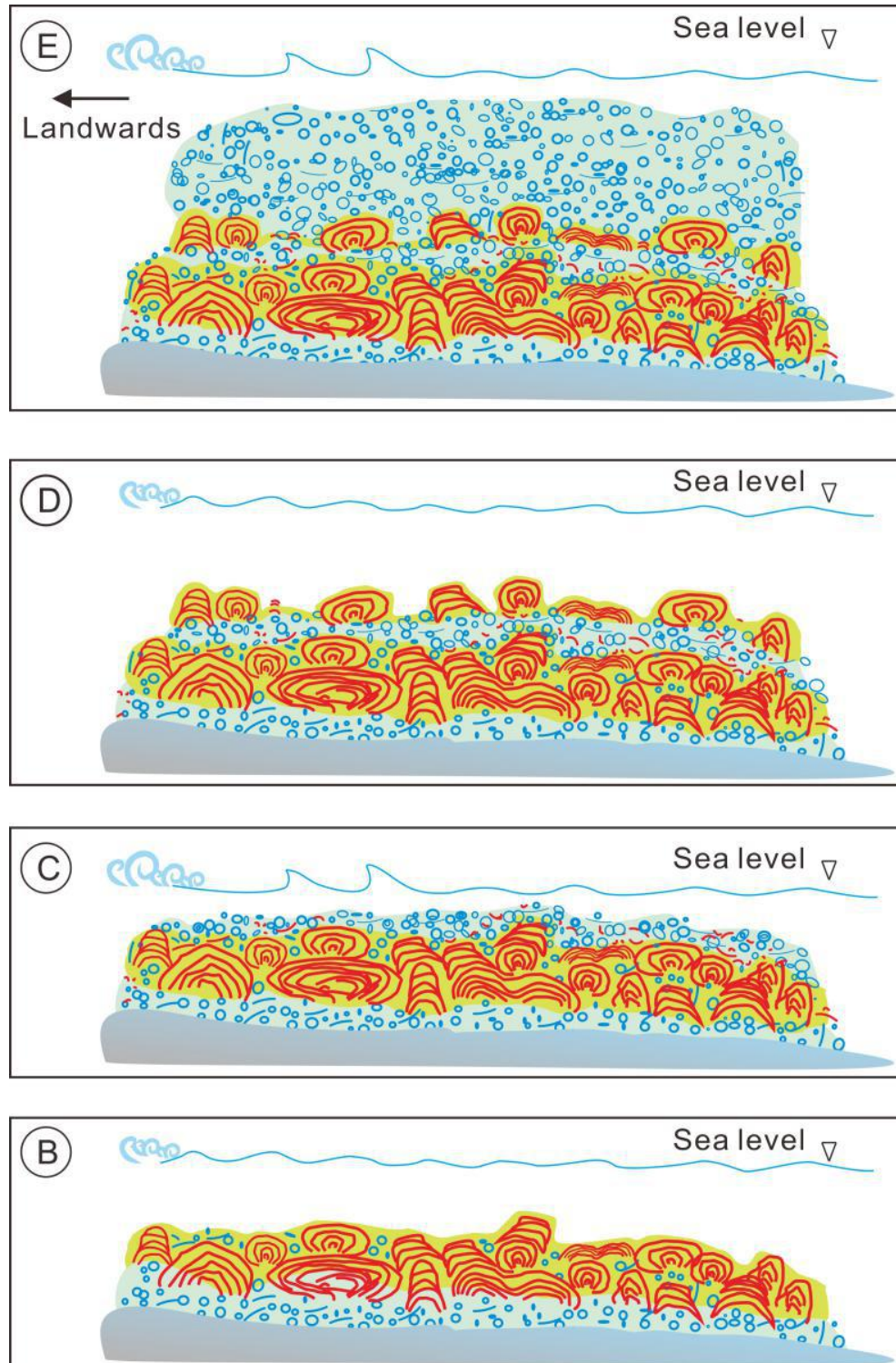

914

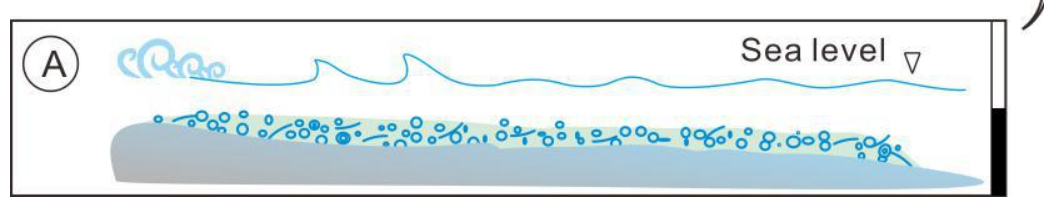

